\title{
Synthesis, Antibacterial Evaluation and in Silico Study of DOTA- fluoroquinolone Derivativessynthesis, Antibacterial Evaluation and in Silico Study of DOTA-fluoroquinolone Derivatives
}

\author{
Weitian Li \\ Chinese Academy of Medical Sciences \& Peking Union Medical College Institute of Biomedical Engineering

\section{Ge Hong} \\ Chinese Academy of Medical Sciences \& Peking Union Medical College Institute of Biomedical Engineering \\ Lina Mao \\ Chinese Academy of Medical Sciences \& Peking Union Medical College Institute of Biomedical Engineering \\ Zengping Xu \\ Chinese Academy of Medical Sciences \& Peking Union Medical College Institute of Biomedical Engineering \\ Jiawen Wang \\ Chinese Academy of Medical Sciences \& Peking Union Medical College Institute of Biomedical Engineering \\ wenzhi Wang \\ Chinese Academy of Medical Sciences \& Peking Union Medical College Institute of Biomedical Engineering \\ Tianjun Liu ( $\square$ liutianjun@hotmail.com ) \\ Chinese Academy of Medical Sciences \& Peking Union Medical College Institute of Biomedical Engineering
}

\section{Research Article}

Keywords: fluoroquinolone, water-soluble, antimicrobial activities, ADMET, cytotoxicity

Posted Date: November 18th, 2021

DOI: https://doi.org/10.21203/rs.3.rs-1066845/v1

License: (c) (i) This work is licensed under a Creative Commons Attribution 4.0 International License. Read Full License 


\section{Abstract}

A series of water-soluble fluoroquinolones based upon DOTA modification were synthesized and characterized by NMR and HRMS spectra. All the newly prepared quinolones compounds exhibited potent antimicrobial activities against MRSA, P. aeruginosa and E. coli. Molecular docking study indicated they could form stable complex with DNA gyrase and topoisomerase IV-DNA respectively, ADMET prediction showed they were low toxicity to the mice as whole. Among them, water-soluble quinolone $4 \mathbf{c}$ exhibited promising antibacterial potency, its MIC, MBC value for MRSA and $P$. aeruginosa was $(1.56,6.25) \mu \mathrm{g} / \mathrm{mL},(3.1,12.5) \mu \mathrm{g} / \mathrm{mL}$ respectively. Atomic Force Microscope (AFM) imaging revealed $\mathbf{4 c}$ could effectively destroy MRSA bacterial membrane and wall, causing its contents to leak out. Cytotoxicity assay showed $\mathbf{4 c}$ had low toxicity to L-02, A549 and MCF-7, over $80 \%$ cell viability even at $100 \mu \mathrm{mol} / \mathrm{L}$. These results showed that water-soluble compound $\mathbf{4 c}$ was a promising antibacterial candidate.

\section{Highlights}

1. A series of water-soluble quinolone antibacterial compounds was synthesized, characterized and antibacterial ability was screened.

2. Compound $\mathbf{4} \mathbf{c}$ showing potent antibacterial activity and low cytotoxicity in vitro.

3. 4c could effectively destroy MRSA bacterial membranes and walls revealed by AFM imaging.

4. Strong affinity of compound $\mathbf{4} \mathbf{c}$ with topoisomerase IV-DNA and DNA gyrase, good ADMET data obtained by molecular docking, MOE and Pre-ADMET calculation.

\section{Introduction}

Fluoroquinolone, as a major class of synthetic antibiotics since the mid-1980s, had many advantages like good chemical stability, broad antibacterial spectrum as well as excellent antibacterial activity, high biological half lifetime, widely distributed ability in tissues and body fluids, excellent penetration rate and therapeutic ratio [1-9]. Up to now, fourth-generation quinolone antibiotics had been applied in clinics. Some third- and fourth-generation quinolone drugs were listed as follows (Figure 1).

However fluoroquinolone drugs had limited water-solubility [10,11], although salt-formation like ciprofloxacin hydrochloride, pazufloxacin mesilate and moxifloxacin hydrochloride, etc., could partially resolve this problem, the solubility-increase was still limited. Conjugating a hydrophilic group on the piperazine ring of the quinolone would be an efficient chemical method [12,13], the typical example was introducing amino acids [14, 15], N-linked glycosylation methods or pegylation [16, 17]. DOTA [18-20], a good chelator used in MRI contrast agent, with merits of both good water solubility and good biocompatibility, could greatly improve the water solubility of poorly soluble drugs [21]. Teichoic acid [22], one of the main components of the bacterial cell wall, could enrich the $\mathrm{Mg}^{2+}$ around the cell via the interaction with a large amount of negative charge on the surface, resulting in an increase in the activity of some synthetases on the cell membrane[23, 24]. DOTA modification could enhance or tune the targeting of the DOTA-drug to the surface of the bacteria by metal chelation. In addition, teichoic acid, glycopeptide at the bacterial wall interaction with DOTA via hydrogen bonding would also raise the concentration of DOTA modified drug at the bacteria wall. The ensemble effect of DOTA modification could promote the drug potency towards bacterial strains. In this paper, fluoroquinolone modified with DOTA moiety, their synthesis and antibiotic efficacy screening would be reported. C-7 position of quinolones usually had N-heterocyclic moiety with NH binding site, which was easy to form new amide derivatives, the synthesized DOTA-fluoroquinolone was outlined as following (Figure 2).

\section{Results And Discussion}

\subsection{Chemistry}

DOTA had four carboxylic groups, direct reaction with fluoroquinolone gave complex products, which was difficult to purify. Therefore, the target compound was synthesized according to the method outlined in Scheme 1. The first cyclen reacted with t-butyl bromoacetate to form tris-N-(t-butyloxycarbonyl methyl) cyclen, 2 , in a yield of $89 \%$ in DMA solution containing $\mathrm{CH}_{3} \mathrm{COONa}$. $\mathrm{N}$-alkylation of commercially available fluoroquinolones $\mathbf{1 a - g}$ (in Figure $\mathbf{1}$ ) gave intermediates $\mathbf{2 a - g}$. The reaction of $\mathbf{2}$ with fluoroquinolone derivative $\mathbf{2 a - g}$ in acetonitrile in the presence of $\mathrm{K}_{2} \mathrm{CO}_{3}$ under heating condition formed the target fluoroquinolones $\mathbf{3 a - g}$. The final product $\mathbf{4 a - g}$ were obtained quantitatively by TFA deprotection of the tert-butyl group of $\mathbf{3 a - g}$. The purity of the compounds were over $95.00 \%$ by HPLC, and among them, $\mathbf{4 c}$ was $98.56 \%$ (Figure 3).

Reagents and condition: (i) $\mathrm{CH}_{3} \mathrm{COONa}, \mathrm{KBr}, \mathrm{NaHCO}_{3}$, DMA, r.t., 5 days; (ii) DMF, TEA, 3-10 h; (iii) $\mathrm{K}_{2} \mathrm{CO}_{3}, \mathrm{CH}_{3} \mathrm{CN}, 50^{\circ} \mathrm{C}, 24$ h; (iv) TFA, r.t., $40-48$ h. 
2.2. $M I C$ and $M B C$ determinations in vitro

MIC and MBC values of $\mathbf{2 a - 4} \mathbf{g}$ along with the control drugs of $\mathbf{1 a - g}$ against MRSA, P. aeruginosa and $E$. coli, were listed in Table 1.

Table 1. In vitro antimicrobial data as MIC $(\mu \mathrm{g} / \mathrm{mL})$ and $\mathrm{MBC}(\mu \mathrm{g} / \mathrm{mL})$ for compounds $\mathbf{1 a - g}, \mathbf{2 a - g}$, 3a-g and $\mathbf{4 a - g}$.

\begin{tabular}{|c|c|c|c|c|c|c|}
\hline \multirow[t]{2}{*}{ Comp. } & \multicolumn{2}{|l|}{ MRSA } & \multicolumn{2}{|c|}{ P. aeruginosa } & \multicolumn{2}{|l|}{ E. coli } \\
\hline & MIC & MBC & MIC & $\mathrm{MBC}$ & MIC & $\mathrm{MBC}$ \\
\hline $1 \mathrm{a}$ & 1.56 & 3.13 & 0.78 & 1.56 & 0.39 & 0.39 \\
\hline $2 a$ & 0.078 & 0.39 & 0.156 & 0.78 & 0.78 & 1.56 \\
\hline $3 a$ & 6.25 & 25 & 12.5 & 12.5 & 50 & 100 \\
\hline $4 a$ & 12.5 & 50 & 25 & 100 & 50 & 100 \\
\hline $1 b$ & 0.78 & 3.13 & 0.78 & 1.56 & 0.39 & 0.39 \\
\hline $2 b$ & 0.39 & 0.39 & 0.39 & 0.78 & 1.56 & 3.12 \\
\hline $3 b$ & 6.25 & 25 & 6.25 & 12.5 & 200 & 200 \\
\hline $4 b$ & 200 & 200 & 200 & 200 & $>200$ & $>200$ \\
\hline $1 \mathrm{c}$ & 0.078 & 0.156 & 0.078 & 0.156 & 0.156 & 0.156 \\
\hline $2 c$ & 0.39 & 0.78 & 0.39 & 0.78 & 3.12 & 6.25 \\
\hline $3 c$ & 1.56 & 6.25 & 3.13 & 12.5 & 100 & 100 \\
\hline $4 c$ & 1.56 & 6.25 & 3.13 & 12.5 & 100 & 100 \\
\hline $1 d$ & 0.78 & 1.56 & 0.78 & 1.56 & 1.56 & 1.56 \\
\hline $2 d$ & 0.312 & 0.625 & 0.312 & 0.625 & 2.5 & 5 \\
\hline $3 d$ & 12.5 & 25 & 12.5 & 25 & 12.5 & 25 \\
\hline $4 d$ & 25 & 50 & 25 & 50 & 25 & 50 \\
\hline $1 e$ & 0.078 & 0.156 & 0.078 & 0.156 & 0.078 & 0.156 \\
\hline $2 e$ & 2.5 & 5 & 0.078 & 0.156 & 5 & 10 \\
\hline $3 e$ & 3.13 & 6.25 & 3.13 & 6.25 & 3.13 & 6.25 \\
\hline $4 e$ & 6.25 & 12.5 & 6.25 & 12.5 & 6.25 & 12.5 \\
\hline $1 f$ & 0.039 & 0.039 & 0.039 & 0.039 & 0.039 & 0.039 \\
\hline $2 f$ & 0.156 & 0.312 & 0.078 & 0.156 & 10 & 20 \\
\hline $3 f$ & 50 & 100 & 50 & 100 & 50 & 100 \\
\hline $4 f$ & 50 & 100 & 50 & 100 & 50 & 100 \\
\hline $1 \mathrm{~g}$ & 0.156 & 0.313 & 0.313 & 0.78 & 0.156 & 0.313 \\
\hline $2 g$ & 12.5 & 50 & 25 & 50 & 12.5 & 50 \\
\hline $3 g$ & $>200$ & $>200$ & $>200$ & $>200$ & $>200$ & $>200$ \\
\hline $4 \mathrm{~g}$ & $>200$ & $>200$ & $>200$ & $>200$ & $>200$ & $>200$ \\
\hline
\end{tabular}

The general trend of the antibiotic activity in Table 1 changed in the order of $\mathbf{1 a - g}>\mathbf{2 a - g}>\mathbf{3 a - g} \geq \mathbf{4 a - g}$. The corresponding fluoroquinolone mother drug showed the potent antibiotic ability, while modification in this paper would lower this ability, the larger the modification skeleton size, the lower the antibiotic ability. In $\mathbf{2 a - g}$ and $\mathbf{3 a - g}$, the modification moieties were hydrophobic, the size effect dominated their antibiotic potency. And the antimicrobial activity of compound $\mathbf{3 a - g}$ were less than that of $\mathbf{2 a - g}$. The possible reason was the large molecular skeleton of compound $\mathbf{3 a - g}$ weakened them to pass across the cell membrane and bind to its target site. In 4a-g, DOTA modification enhanced their water solubility at the cost of their antibiotic activity. Although the molecular skeleton of the compound $\mathbf{3 a - g}$ is larger than their corresponding 
deprotection product $\mathbf{4 a - g}$, their antibacterial activity was higher. These differences possibly came from the balance of the hydrophilicity and lipophilicity, which influenced the cellular uptake and the following function site binding, finally determined the antibacterial potency.

However the extraordinary was antibacterial potency of $\mathbf{1 a}<\mathbf{2 a}, \mathbf{1} \mathbf{b}<\mathbf{2 b}$ for MRSA and $P$. aeruginosa: for MRSA the MIC MBC value changed from $1 \mathbf{a}(1.56,3.13)$ to $\mathbf{2 a}(0.078,0.39) \mu \mathrm{g} / \mathrm{mL}, \mathbf{1 b}(0.78,3.13)>\mathbf{2 b}(0.39,0.39) \mu \mathrm{g} / \mathrm{mL}$; and for $P$. aeruginosa, $1 \mathrm{a}(0.78,1.56)$ to $2 \mathrm{a}(0.156$, $0.78) \mu \mathrm{g} / \mathrm{mL}, \mathbf{1} \mathbf{b}(0.78,1.56)>\mathbf{2} \mathbf{b}(0.39,0.78) \mu \mathrm{g} / \mathrm{mL}$. While for $E$. coli, the potency changed in the order of $\mathbf{1} \mathbf{b}>\mathbf{2} \mathbf{b}, \mathbf{1} \mathbf{a}>\mathbf{2 a}$. This indicated that the antibacterial potency of the compound was also dependent on the strain type. In the whole system studied here, the compound whose antibiotic potency changed less after DOTA modification were $\mathbf{3 c}$ and $\mathbf{4 c}, \mathbf{3 e}$ and $\mathbf{4 e}$. $\mathbf{3 c}$ and $\mathbf{4 c}$ showed the same MIC and MBC value for MRSA, $(1.56,6.25) \mu \mathrm{g} / \mathrm{mL}$ and $(3.13,12.5) \mu \mathrm{g} / \mathrm{mL}$ for $P$. aeruginosa. For $E$. coli, $\mathbf{3 c}$ and $\mathbf{4 c}$ almost lost their potency, at the level of $100 \mu \mathrm{g} / \mathrm{mL}$. While $\mathbf{3 e}$ and $\mathbf{4 e}$ possessed the strong antibacterial potency for the three strains studied here, the MIC and MBC of $\mathbf{3 e}$ and $\mathbf{4 e}$ for MRSA or $P$. aeruginosa was $(3.13,6.25) \mu \mathrm{g} / \mathrm{mL}$, and for $E$. coli was $(6.25,12.5) \mu \mathrm{g} / \mathrm{mL}$ respectively.

In 1a-e, with piperazine ring at the C-7 position in common, so the antibiotic trend for their derivative like $2 \mathrm{a}-\mathbf{e}$, 3a-e, $4 a-e$ changed roughly in the same way. While in $\mathbf{1} \mathbf{f}$ and $\mathbf{1} \mathbf{g}$, with fused bicyclic or cyclopropyl ring at C-7 respectively, their antibiotic potency changed differently, modification with DOTA made them almost lose completely their antibiotic activity. For the three strains reported here, MRSA, $P$. aeruginosa and $E$. coli, MIC and MBC value changed from $(0.039,0.039) \mu \mathrm{g} / \mathrm{mL}$ in $1 \mathrm{f}$ to over $(50,100) \mu \mathrm{g} / \mathrm{mL}$ in $3 \mathbf{f}, 4 \mathbf{f} ;(0.156,0.313) \mu \mathrm{g} / \mathrm{mL}$ in $1 \mathrm{~g}$ to over $(200,200) \mu \mathrm{g} / \mathrm{mL}$ in $\mathbf{3 g}, \mathbf{4} \mathbf{g}$. The possible interpretation is due to the function of fluoroquinolone antibiotics on topoisomerase IV and DNA gyrase $[3,25,26]$, inner of the cell, the large molecular skeleton would weaken the molecule ensemble pass across the cell membrane.

The DOTA-quinolone (4a-g) could complex with metal ions such as Fe ${ }^{2+}, \mathrm{Mg}^{2+}, \mathrm{Mn}^{2+}$ in the form of $1: 1$ ratio, which was confirmed by ESI-MS. However, the metal ions' effect on the antibacterial of DOTA-modified quinolone compounds revealed that these metal ions docking just improved a little in antibacterial activity, such as the MIC, MBC data of 4 a for MRSA was $(12.5,50) \mu \mathrm{g} / \mathrm{mL}, \mathrm{for} P$. aeruginosa $(25,100) \mu \mathrm{g} / \mathrm{mL}$, while the data of $4 a-F e$ was $(5,20) \mu \mathrm{g} / \mathrm{mL},(10,20) \mu \mathrm{g} / \mathrm{mL}$, respectively. These results supported our original suggestion: these complexes could enrich the DOTA-quinolone compounds at the surface of bacterial walls. But their potency just improved a limited bit, was still weaker than the mother drug $\mathbf{1 a - g}$, so the detailed study for the other DOTA compounds was stopped.

\subsection{Prediction of ADMET property}

Table 2. The ADMET properties of compound $1 \mathbf{a}-\mathbf{4 g}$. 


\begin{tabular}{|c|c|c|c|c|c|c|c|c|c|c|c|c|}
\hline \multirow[t]{2}{*}{ Comp. } & \multicolumn{8}{|c|}{ Drug Likeness } & \multicolumn{2}{|l|}{ ADME } & \multicolumn{2}{|l|}{ Toxicty } \\
\hline & $M^{a}$ & $\operatorname{cog} P^{a}$ & $H B D^{b}$ & $H B A^{b}$ & RBN $^{b}$ & $A S A^{b}$ & ASA_Pb & $\begin{array}{l}\text { Rule } \\
\text { of } \\
\text { Five }\end{array}$ & CYP2D6C & $\mathrm{PPB}^{\mathrm{c}}$ & Carcino_Mc & hERG ${ }^{c}$ \\
\hline $1 a$ & 331.13 & -0.73 & 2 & 6 & 3 & 301.52 & 216.83 & 0 & 0 & 31.05 & 0 & 0 \\
\hline $1 b$ & 334.16 & -0.78 & 2 & 6 & 3 & 298.57 & 193.46 & 0 & 0 & 24.29 & 0 & 0 \\
\hline $1 c$ & 375.16 & -0.27 & 2 & 7 & 4 & 314.16 & 216.06 & 0 & 0 & 32.76 & 0 & 0 \\
\hline $1 d$ & 320.13 & -1.60 & 2 & 7 & 3 & 301.23 & 209.59 & 0 & 0 & 23.33 & 0 & 0 \\
\hline $1 e$ & 389.18 & -0.36 & 2 & 7 & 5 & 326.11 & 227.66 & 0 & 1 & 39.22 & 0 & 0 \\
\hline $1 f$ & 401.18 & -0.08 & 2 & 7 & 4 & 337.22 & 221.10 & 0 & 0 & 42.99 & 0 & 0 \\
\hline $1 \mathrm{~g}$ & 318.10 & -1.19 & 2 & 6 & 2 & 284.15 & 220.20 & 0 & 1 & 19.23 & 0 & 0 \\
\hline $2 a$ & 407.10 & 1.75 & 1 & 7 & 5 & 346.07 & 293.87 & 0 & 0 & 78.39 & 1 & 0 \\
\hline $2 b$ & 395.10 & 1.70 & 1 & 7 & 5 & 343.12 & 270.21 & 0 & 0 & 71.64 & 1 & 0 \\
\hline $2 c$ & 451.13 & 2.21 & 1 & 8 & 6 & 350.15 & 291.09 & 0 & 0 & 75.47 & 1 & 0 \\
\hline $2 d$ & 396.10 & 0.88 & 1 & 8 & 5 & 345.78 & 289.08 & 0 & 0 & 66.46 & 1 & 0 \\
\hline $2 e$ & 465.15 & 2.48 & 1 & 8 & 7 & 358.63 & 304.80 & 0 & 0 & 80.17 & 1 & 0 \\
\hline $2 f$ & 477.15 & 2.30 & 1 & 8 & 6 & 362.62 & 289.57 & 0 & 0 & 81.65 & 1 & 0 \\
\hline $2 g$ & 394.07 & 1.55 & 2 & 7 & 5 & 304.56 & 274.88 & 0 & 0 & 68.93 & 0 & 0 \\
\hline $3 a$ & 885.50 & 2.06 & 1 & 17 & 18 & 611.86 & 280.21 & 3 & 0 & 25.67 & 0 & 1 \\
\hline $3 b$ & 873.50 & 2.01 & 1 & 17 & 18 & 612.15 & 245.65 & 3 & 0 & 24.57 & 0 & 1 \\
\hline $3 c$ & 929.52 & 2.52 & 1 & 18 & 19 & 614.60 & 282.05 & 3 & 0 & 26.72 & 0 & 1 \\
\hline $3 d$ & 874.50 & 1.19 & 1 & 18 & 18 & 614.81 & 277.86 & 3 & 0 & 23.58 & 0 & 0 \\
\hline $3 e$ & 943.54 & 2.66 & 1 & 18 & 20 & 607.83 & 274.74 & 3 & 0 & 28.80 & 0 & 1 \\
\hline $3 f$ & 955.54 & 2.62 & 1 & 18 & 19 & 630.31 & 291.69 & 3 & 0 & 28.02 & 0 & 1 \\
\hline $3 g$ & 872.47 & 1.43 & 2 & 17 & 18 & 564.61 & 285.61 & 3 & 0 & 19.87 & 0 & 1 \\
\hline $4 a$ & 717.31 & -5.51 & 4 & 17 & 12 & 512.70 & 521.57 & 3 & 0 & 11.36 & 0 & 1 \\
\hline $4 b$ & 705.31 & -5.50 & 4 & 17 & 12 & 510.50 & 476.65 & 3 & 0 & 11.14 & 0 & 1 \\
\hline $4 c$ & 761.34 & -4.99 & 4 & 18 & 13 & 515.44 & 515.30 & 3 & 0 & 11.42 & 0 & 1 \\
\hline $4 d$ & 706.30 & -6.32 & 4 & 18 & 12 & 513.16 & 515.53 & 3 & 0 & 11.01 & 0 & 0 \\
\hline $4 e$ & 775.36 & -4.85 & 4 & 18 & 14 & 515.77 & 489.39 & 3 & 0 & 11.90 & 0 & 1 \\
\hline $4 f$ & 787.36 & -4.90 & 4 & 18 & 13 & 520.94 & 478.92 & 3 & 0 & 11.63 & 0 & 1 \\
\hline $4 \mathrm{~g}$ & 704.28 & -6.08 & 5 & 17 & 12 & 458.66 & 485.18 & 3 & 0 & 10.61 & 0 & 2 \\
\hline
\end{tabular}

${ }^{a} \mathrm{MW}$ (molecular weight) and $\operatorname{cog} P$ values were calculated by Chem Draw Ultra 14.0.

${ }^{\mathrm{b}} \mathrm{HBD}$ (number of hydrogen bond donors), HBA (number of hydrogen bond acceptors), RBN (number of rotatable bonds), ASA (water accessible surface area) and ASA_P (total polar surface area), Lipinski's rule of five are: $\mathrm{MW}<500, \operatorname{cog} P<5, \mathrm{HBD} \leq 5, \mathrm{HBA} \leq 10, \mathrm{RBN} \leq 10$. Compounds that satisfy these rules are considered druglike. Here the prediction was conducted using MOE 2008.10 [27, 28]. 0, 3 indicated zero or three violation items of Lipinski's rule of five.

${ }^{\mathrm{C}}$ CYP2D 6 (CYP2D6 inhibition) Cytochrome P450 2D6 inhibition in vitro. 0 = non inhibitor, 1 = inhibitor., PPB (plasma protein binding) plasma protein binding (\%) in vitro., Carcino_M (carcinogenicity Mouse) Carcinogenicity bioassay in mouse. $0=$ negative, $1=$ positive.

and hERG (hERG inhibition) human ether-a-go-go-related gene channel inhibition in vitro. $0=$ low risk, $1=$ medium risk, $2=$ high risk, $3=$ ambiguous. were calculated via Pre-ADMET ver 2.0 (Yonsei University, Seoul, Korea, https://preadmet.bmdrc.kr/) [29]. 
The prediction of ADMET (absorption, distribution, metabolism, excretion and toxicity) properties of all the target compounds $\mathbf{1 a - 4 g}$ were presented in Table 2. The solubility of the compounds correlated tightly with its ADMET. Log $P$ values could reflect the lipophilicity of compounds[30], the smaller the $\log P$ value, the more hydrophilic the molecule. Similarly, the opposite was the change of lipophilicity. Table 2 showed that the $\log P$ of compounds $\mathbf{2} \mathbf{a - g}$ and $\mathbf{3 a - g}$ were larger than zero, suggesting their lipophilic properties, while less zero data for $\mathbf{4 a - g}$ and these data were even less $\mathbf{1 a - g}$ suggesting its good hydrophilicity. $\mathbf{3 a - 4} \mathbf{g}$ did not meet Lipinski's rule of five, their molecular weight was over 500, the number of HBA and total rotation bonds were more than 10. The cytochrome P450 2D6 (CYP2D6) was involved in the metabolism of a wide range of substrates in the liver and its inhibition by a drug constitutes a majority case of drug-drug interaction [31, 32]. Based upon Pre-ADMET ver 2.0 computation, the target compounds $\mathbf{1 a - 4 g}$ interaction with CYP2D 6 was conducted. Results showed that except for $\mathbf{1 e}, \mathbf{1 g}$, compounds $\mathbf{1 a - 4 g}$ were found to be non-inhibitors of cytochrome P450 2D6. No carcinogenicity to mice was predicted for compounds of $\mathbf{1 a - 1 g , ~} \mathbf{2 g}, \mathbf{3 a - 3 g}$ and $\mathbf{4 a - 4 g}$ compounds. Except for $\mathbf{3 d}$ and $\mathbf{4 d}$, medium risk in toxicity to heart was predicted for $\mathbf{3 a - 4 g}$, while $\mathbf{4 g}$ showed more risk in this case. In general, DOTA modification of fluoroquinolone in this paper actually increased the water solubility of the ensemble system $\mathbf{4 a - g}$, no carcinogenicity, no toxicity to heart and no toxicity to P450 were predicted, however the change in molecular weight, the binding site as well as the ADMET, caused an ensemble effect in antibacterial activity listed in Table 1.

\subsection{Molecular docking studies}

Type IIA topoisomerases played an important role in the regulation of DNA replication, recombination and transcription for all bacteria [33]. It was well known that two bacterial type IIA topoisomerases, DNA gyrase and topoisomerase IV, were therapeutic targets for quinolone antibiotics [3], which were very potent against both Gram-negative and Gram-positive bacteria [34]. Study on interaction between type IIA topoisomerases and their inhibitors were crucial for novel quinolones design. To rationalize the observed antibacterial activity of the compounds $\mathbf{1 a - 4 g}$, a flexible ligand docking study was conducted. The crystal structure data of DNA gyrase [PDB ID: 2XCT] [34] and topoisomerase IV-DNA [PDB ID: 4KPF] [35]were obtained from a protein database, and compound 4c interaction with 2XCT and 4KPF was outlined as an example. Table 3 listed the molecular docking results.

Table 3. Docking results of $1 \mathrm{a}-\mathbf{4 g}$ with $2 \mathrm{XCT}$ and $4 \mathrm{KPF}$. 


\begin{tabular}{|c|c|c|c|c|c|c|}
\hline \multirow[t]{2}{*}{ Comp. } & \multicolumn{3}{|l|}{$2 X C T$} & \multicolumn{3}{|l|}{ 4KPF } \\
\hline & $\mathrm{DS}^{\mathrm{a}}$ & GE $^{\mathrm{a}}$ & $\mathrm{LE}^{\mathrm{a}}$ & $\mathrm{DS}^{\mathrm{a}}$ & $\mathrm{GE}^{\mathrm{a}}$ & $\mathrm{LE}^{\mathrm{a}}$ \\
\hline $1 a$ & -5.76 & -35.37 & -0.24 & -11.78 & -63.13 & -0.49 \\
\hline $1 b$ & -6.10 & -36.35 & -0.27 & -11.64 & -58.65 & -0.51 \\
\hline $1 c$ & -5.30 & -37.82 & -0.20 & -12.12 & -65.82 & -0.45 \\
\hline $1 d$ & -4.98 & -28.62 & -0.22 & -11.04 & -54.17 & -0.48 \\
\hline $1 e$ & -5.83 & -43.16 & -0.21 & -11.64 & -64.28 & -0.42 \\
\hline $1 f$ & -5.77 & -42.20 & -0.20 & -11.57 & -62.55 & -0.40 \\
\hline $1 \mathrm{~g}$ & -5.93 & -36.83 & -0.26 & -9.78 & -51.52 & -0.43 \\
\hline $2 a$ & -5.03 & -43.31 & -0.18 & -9.58 & -56.05 & -0.34 \\
\hline $2 b$ & -4.82 & -40.74 & -0.18 & -9.82 & -55.08 & -0.36 \\
\hline $2 c$ & -3.87 & -41.92 & -0.12 & -9.79 & -56.28 & -0.32 \\
\hline $2 d$ & -5.39 & -43.42 & -0.20 & -9.44 & -54.83 & -0.35 \\
\hline $2 e$ & -4.03 & -44.26 & -0.13 & -9.75 & -56.50 & -0.30 \\
\hline $2 f$ & -4.57 & -46.75 & -0.14 & -10.02 & -62.76 & -0.30 \\
\hline $2 g$ & -3.70 & -34.29 & -0.14 & -8.83 & -49.47 & -0.33 \\
\hline $3 a$ & -7.93 & -71.36 & -0.13 & -14.69 & -103.76 & -0.23 \\
\hline $3 b$ & -7.80 & -79.69 & -0.13 & -15.02 & -98.88 & -0.24 \\
\hline $3 c$ & -8.16 & -75.77 & -0.12 & -14.75 & -103.64 & -0.22 \\
\hline $3 d$ & -7.92 & -72.61 & -0.13 & -14.95 & -104.46 & -0.24 \\
\hline $3 e$ & -8.00 & -72.87 & -0.12 & -14.91 & -110.54 & -0.22 \\
\hline $3 f$ & -8.48 & -78.77 & -0.12 & -16.15 & -108.05 & -0.24 \\
\hline $3 g$ & -7.11 & -68.42 & -0.11 & -9.77 & -74.73 & -0.16 \\
\hline $4 a$ & -8.39 & -70.37 & -0.16 & -13.10 & -82.16 & -0.26 \\
\hline $4 b$ & -7.91 & -71.16 & -0.16 & -12.86 & -80.46 & -0.26 \\
\hline $4 c$ & -8.03 & -67.04 & -0.15 & -13.43 & -78.12 & -0.25 \\
\hline $4 d$ & -7.40 & -64.45 & -0.15 & -13.31 & -82.71 & -0.27 \\
\hline $4 e$ & -8.38 & -67.89 & -0.15 & -13.28 & -82.11 & -0.24 \\
\hline $4 f$ & -7.78 & -67.70 & -0.14 & -13.77 & -81.46 & -0.25 \\
\hline $4 g$ & -7.12 & -61.03 & -0.14 & -11.98 & -67.57 & -0.24 \\
\hline IUV & - & - & - & -12.12 & -69.42 & -0.45 \\
\hline CPF & -6.19 & -40.45 & -0.26 & - & - & - \\
\hline
\end{tabular}

${ }^{a}$ DS (Docking score, kcal/mol), GS (Glide energy, kcal/mol), LE (Glide ligand efficiency, kcal/mol),

The data of Table 3 docking score and glide energy[36] revealed that most synthesized quinolones in this paper exhibited high binding affinity towards the two proteins, 2XCT and 4KPF, lower binding energy than the co-crystallized ligands revealed a more stable complex than that of the co-crystallized ligand. And these energy trends did not match well with the antibacterial results in Table 1. The ensemble binding energy was dependent upon the total interaction area, the larger total interaction area caused lower energy and resulted in strong affinity. However the energy contribution for each group was unequal, the rationalized design should outline each moiety contribution, i.e., each group was necessary other than auxiliary. Based upon this consideration, the ligand efficiency (LE) [37] for each group in the quinolones 1a- 
$\mathbf{4 g}$ was evaluated again, and LE ran in the order of $\mathbf{1 a - 1 g}<\mathbf{2 a - 2 g}<\mathbf{3 a - 3 g} \approx \mathbf{4 a - 4 g}$, which was roughly consistent with antibacterial results in Table 1.

As an example of the good docking poses, compound $\mathbf{4 c}$ in the active site of DNA gyrase and topoisomerase IV were shown (in Figure 4). Although compounds $\mathbf{1 a - g}, \mathbf{2 a - g}$ had more potent activity than $\mathbf{4 c}$, the mother compounds like $\mathbf{1 a - g}$ were the clinical drugs, the reaction intermediate like $\mathbf{2 a - g}$ was reported before [38], in this paper we tried to investigate the DOTA modification effect on the fluoroquinolone activity, and $4 \mathrm{c}$ was the most potent one among DOTA-fluoroquinolone series, so a rational explanation based upon the 3D and 2D docking model was given to $\mathbf{4 c}$. Compound $\mathbf{4 c}$ was well accommodated inside the active site of DNA gyrase (A, B) in the predicted model. The DOTA

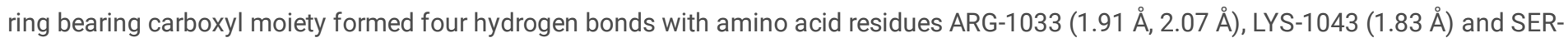
1085 (2.11 $\AA$ ). Moreover, the quinolone parent ring bearing carboxylic group was closely linked to the adjacent residues ALA-439 (2.04 $\AA$ ) and GLY-584 (1.88 A) via another two hydrogen bonds. In the predicted model of topoisomerase IV (C, D), compound $\mathbf{4 C}$ was also well accommodated inside the active site, the quinolone parent ring intercalated into the hydrophobic pocket of the receptor with a hydrogen bond between the oxygen atom of carboxyl moiety and SER-79 (1.72 Å). The DOTA ring bearing carboxylic group was closely linked to the adjacent residues LYS-415 (1.67 $\AA$ ) via another hydrogen bond. Overall, the 3D and 2D docking models provided a rational explanation for why compound $\mathbf{4 c}$ had a strong inhibitory efficacy against bacteria.

\subsection{Damaged cell wall monitored by atomic force microscope (AFM)}

AFM images of strains could reveal some detailed information. The representative results are shown (in Figure 5). Under normal condition without any treatment, MRSA (in Figure 5) (a) showed a normal ball-shaped structure, the shape and size were similar to that reported in previous studies $[39,40]$. However, MRSA ruptured into fragments upon being treated with compounds $1 \mathrm{c}$ and $4 \mathrm{c}$ (in Figure 5) (b-f). Treated by $10 \mu \mathrm{mol} / \mathrm{L}$ gatifloxacin (1c), MRSA showed obvious cracks on the surface (in Figure 5) (b), although its ball shape was similar to that of untreated in general, some of them was broken into irregular fragments. These morphologic changes correlated tightly with their death and division ability. While treated by $10 \mu \mathrm{mol} / \mathrm{L}$ gatifloxacin-DOTA (4c), the spherical shape of MRSA strain was completely broken into fragments and clustered together, with apparent leakage of the cell contents (in Figure 5) (d-f). The possible interpretation was that the damage of $\mathbf{4 c}$ to the strains broke the balance between the inner and outer osmotic pressures of the cell, resulting in the loss of inner contents and consequently cell death. Generally, the AFM images of the size, shape and leakage with the cell contents of the bacteria agreed well with the report in the previous study $[41,42]$. The morphological imaging result demonstrated the potent antibacterial activity of $\mathbf{4 c}$.

\subsection{Cytotoxicity assay in vitro with L-02 cell, A549 cell and MCF-7 cell}

Compound 4c showed potent antibacterial activity, so its cytotoxicity towards different cell lines was studied (shown in Figure 6). For clarity the mother compound $1 \mathrm{c}$ as control was studied. Both $\mathbf{4 c}$ and $1 \mathrm{c}$ did not show significant toxicity to normal hepatocytes L-02 cell (A), A549 cell (B) and MCF-7 cell (C), except a limited difference. $4 \mathrm{c}$ had low toxicity to the cell lines studied, more than $80 \%$ cell viability was obtained even at $100 \mu \mathrm{mol} / \mathrm{L}$, which was consistent with the toxicity of ADMET prediction results in Table 2 . The antibacterial MIC and MBC value of $\mathbf{4 c}$ were $(1.56,6.25) \mu \mathrm{g} / \mathrm{mL}$ for MRSA and $(3.13,12.5) \mu \mathrm{g} / \mathrm{mL}$ for $P$. aeruginosa respectively, at $2 \sim 16 \mu \mathrm{mol} / \mathrm{L}$ level, much less than $100 \mu \mathrm{mol} / \mathrm{L}$, so $\mathbf{4 c}$ was safe and promising as an antibacterial agent.

\section{Conclusion}

In summary, a series of novel water-soluble quinolone antimicrobial based upon DOTA modification were synthesized and characterized, with their bacteriostatic and bactericidal activities evaluated. Based upon Pre-ADMET ver 2.0 computation, most of the compounds obtained were predicted no toxicity to mice, slightly toxicity to the heart. Molecular docking studies indicated its strong binding affinity towards DNA gyrase and topoisomerase IV, correlated with its antibacterial mechanism. Among them, a novel water-soluble quinolone compound $4 \mathbf{c}$ with good antibacterial activity was discovered, the value of MIC and MBC was $(1.56,6.25) \mu \mathrm{g} / \mathrm{mL}$ against MRSA, $(3.13,12.5) \mu \mathrm{g} / \mathrm{mL}$ against $P$. aeruginosa. It had low cellular toxicity, over $80 \%$ cellular availability even at over $100 \mu \mathrm{M}$. AFM revealed that $\mathbf{4 c}$ could destroy bacterial walls and membranes. Overall, these results suggested that DOTA modification actually could improve the water-soluble of quinolone structure, although at cost of limited antibacterial activity; compound 4c exhibited promising characteristics worth of studying further as a novel antibacterial agent.

\section{Experimental Section}

\section{1. chemistry}

High resolution mass spectra (HRMS) were recorded on Agilent 6520 Q-TOF LC/MS or Varian 7.0T FTMS (MALDI). ${ }^{1} \mathrm{H}$ NMR spectra and ${ }^{13} \mathrm{C}$ NMR were acquired on a Mercury Vx-300 (300 MHz) or Bruker AVANCE III (400 MHz) and referenced to tetramethylsilane (TMS). The residual 
solvent line was used as an internal standard and the chemical shift was reported in ppm ( $\delta$ ), Compounds were purified by silica gel column (200 - 300 mesh). The reaction process was detected by thin-layer chromatography (TLC) on silica gel GF254 plates (Qingdao Haiyang Chemical Plant, Qingdao, China) and the spots were observed with iodine or UV lamps $(\lambda=254 \mathrm{~nm}, 365 \mathrm{~nm})$, The purity of the compounds was tested over $95.00 \%$ by HPLC (Waters 2695 Alliance system), with Kromasil 100-5-C18 column $4.6 \times 250 \mathrm{~mm}$, eluted by A/B $=32: 68$ ( $\mathrm{A}$, acetonitrile: methanol $=70: 30 ; \mathrm{B}$, water: methanol $=95: 5$ ) containing $0.1 \%$ TFA at a flow rate of $1 \mathrm{~mL} / \mathrm{min}$.

\subsection{Synthesis of tri-tert-butyl 2,2',2"-(1,4,7,10-tetraazacyclododecane-1,4,7-triyl)triacetate (2)}

$10.0 \mathrm{~g}$ ( 1 eq, $58.05 \mathrm{mmol})$ cyclen (1,4,7,10-tetraazacyclododecane) and $14.3 \mathrm{~g}$ (3 eq, $174.14 \mathrm{mmol}$ sodium acetate were dissolved in $134 \mathrm{~mL}$ DMA, stirred in an ice water bath at $0{ }^{\circ} \mathrm{C}$ for 30 minutes, then $26 \mathrm{~mL}$ (3 eq, $174.14 \mathrm{mmol}$ ) tert-butyl bromoacetate in $50 \mathrm{~mL}$ DMA was added dropwise in 30 minutes. The slurry was stirred at room temperature for 5 days. $10.0 \mathrm{~g}(1.5 \mathrm{eq}, 87.07 \mathrm{mmol}) \mathrm{KBr}$ in $660 \mathrm{~mL}$ of deionized water was heated to $50{ }^{\circ} \mathrm{C}$, then was added to the slurry forming a yellow color solution. The pH of the solution was adjusted to $8-9$ with $\mathrm{Na}_{2} \mathrm{CO}_{3}$. After filtration, the filter cake was washed with deionized water, then dried under a vacuum condition to give $26.5 \mathrm{~g}$ white solid powder, in a yield of $89 \%$. ${ }^{1} \mathrm{H} \mathrm{NMR}\left(300 \mathrm{MHz}, \mathrm{CDCl}_{3}\right) \delta 3.37(\mathrm{~s}, 4 \mathrm{H}), 3.28(\mathrm{~s}, 2 \mathrm{H}), 3.09-3.08(\mathrm{~m}, 4 \mathrm{H}), 2.91-2.88(\mathrm{~m}, 12 \mathrm{H}), 2.17(\mathrm{~s}, 1 \mathrm{H}), 1.46(\mathrm{~s}, 27 \mathrm{H}) . \mathrm{HRMS}$ (MALDI) m/z $515.3806[\mathrm{M}+\mathrm{H}]^{+}$, calcd. for $\left[\mathrm{C}_{26} \mathrm{H}_{51} \mathrm{~N}_{4} \mathrm{O}_{6}\right]^{+}, 515.3809$.

\subsection{Synthesis of compound $2 a-g$}

$0.32 \mathrm{~g}$ (1.0 eq, $1 \mathrm{mmol}) 1 \mathrm{a}$ was dissolved in $10 \mathrm{~mL}$ water-free DMF, and $150 \mu \mathrm{L}(1.5 \mathrm{eq}, 1.5 \mathrm{mmol})$ TEA and $169 \mu \mathrm{L}(2.2 \mathrm{eq}, 2.2 \mathrm{mmol})$ chloroacetyl chloride were added in sequence. The solution was stirred at room temperature for $24 \mathrm{~h}$, After the reaction completion detected by TLC, $30 \mathrm{~mL}$ of deionized water was added. After filtration, the filter cake was washed with deionized water and dried overnight in the vacuum chamber, $0.27 \mathrm{~g}$ of the target compound $2 \mathrm{a}$ was obtained in a yield of $73 \%$.

Compound $\mathbf{2 b - g}$ was synthesized in the same way as compound $\mathbf{2 a}$ in yields of $70-88 \%$.

\subsubsection{7-(4-(2-chloroacetyl)piperazin-1-yl)-1-cyclopropyl-6-fluoro-4-oxo-1,4-dihydroquinoline}

\section{-3-carboxylic acid (2a)}

Compound 2a, $0.27 \mathrm{~g}$ was obtained, white solid, yield $73 \%,{ }^{1} \mathrm{H}$ NMR $\left(300 \mathrm{MHz}, \mathrm{CDCl}_{3}\right), \delta 14.86(\mathrm{~s}, 1 \mathrm{H},-\mathrm{COOH}), 8.79\left(\mathrm{~s}, 1 \mathrm{H},-\mathrm{C}_{2} \mathrm{H}\right), 8.07(\mathrm{~d}$, $\left.J=12.48 \mathrm{~Hz}, 1 \mathrm{H},-\mathrm{C}_{5} \mathrm{H}\right), 7.39\left(\mathrm{~d}, J=6.99 \mathrm{~Hz}, 1 \mathrm{H},-\mathrm{C}_{8} \mathrm{H}\right), 4.14\left(\mathrm{~s}, 2 \mathrm{H},-\mathrm{CH}_{2} \mathrm{Cl}\right), 3.91-3.88(\mathrm{~m}, 2 \mathrm{H}, 2$-piperazine- $\mathrm{H}), 3.82-3.79\left(\mathrm{~m}, 2 \mathrm{H}, 2^{\prime \prime}-\right.$

piperazine-H), 3.56, 3.44 - 3.41 (m, 2H, 3'-piperazine-H ), 3.35 - $3.33\left(\mathrm{~m}, 2 \mathrm{H}, 3^{\prime \prime}\right.$-piperazine-H), 1.44 - $1.42\left(\mathrm{~m}, 2 \mathrm{H},-\mathrm{NCHCH}_{2}\right), 1.29$ - $1.26(\mathrm{~m}, 1 \mathrm{H}$, $\mathrm{NCH}), 1.24$ - $1.23\left(\mathrm{~m}, 2 \mathrm{H},-\mathrm{NHCHCH}_{2}\right)$. HRMS (ESI) m/z $408.1116[\mathrm{M}+\mathrm{H}]^{+}$, calcd. for $\left[\mathrm{C}_{19} \mathrm{H}_{20} \mathrm{ClFN}_{3} \mathrm{O}_{4}\right]^{+}, 408.1126$.

\subsubsection{7-(4-(2-chloroacetyl)piperazin-1-yl)-1-ethyl-6-fluoro-4-oxo-1,4-dihydroquinoline-3-}

carboxylic acid (2b)

Compound 2b, $0.29 \mathrm{~g}$ was obtained, white solid, yield $83 \%,{ }^{1} \mathrm{H} \mathrm{NMR}\left(300 \mathrm{MHz}, \mathrm{CDCl}_{3}\right), \delta 14.92(\mathrm{~s}, 1 \mathrm{H},-\mathrm{COOH}), 8.70\left(\mathrm{~s}, 1 \mathrm{H},-\mathrm{C}_{2} \mathrm{H}\right), 8.13(\mathrm{~d}, J=$ $\left.11.1 \mathrm{~Hz}, 1 \mathrm{H},-\mathrm{C}_{5} \mathrm{H}\right), 6.85\left(\mathrm{~d}, J=7.5 \mathrm{~Hz}, 1 \mathrm{H},-\mathrm{C}_{8} \mathrm{H}\right), 4.36-4.33\left(\mathrm{~m}, 2 \mathrm{H},-\mathrm{N}^{-} \mathrm{CH}_{2}\right), 4.14\left(\mathrm{~s}, 2 \mathrm{H},-\mathrm{CH}_{2} \mathrm{Cl}\right), 3.91$ - $3.88(\mathrm{~m}, 2 \mathrm{H}, 2$, - piperazine- $\mathrm{H}), 3.82$ $3.78\left(\mathrm{~m}, 2 \mathrm{H}, 2^{\prime}\right.$-piperazine-H), 3.43 - 3.37 (m, 2H, 3'-piperazine-H), 3.34 - $3.30(\mathrm{~m}, 2 \mathrm{H}, 3$ ", -piperazine- $\mathrm{H}), 1.28$ - $1.27\left(\mathrm{~m}, 3 \mathrm{H},-\mathrm{NCH}_{2} \underline{\mathrm{CH}}_{3}\right)$. HRMS (ESI) $\mathrm{m} / \mathrm{z} 396.1120[\mathrm{M}+\mathrm{H}]^{+}$, calcd. for $\left[\mathrm{C}_{18} \mathrm{H}_{20} \mathrm{ClFN}_{3} \mathrm{O}_{4}\right]^{+}, 396.1126$.

\subsubsection{7-(4-(2-chloroacetyl)-3-methylpiperazin-1-yl)-1-cyclopropyl-6-fluoro-8-methoxy-4-}

oxo-1,4-dihydroquinoline-3-carboxylic acid (2c)

Compound 2c, $0.30 \mathrm{~g}$ was obtained, white solid, yield 71\%, ${ }^{1} \mathrm{H} \mathrm{NMR}\left(300 \mathrm{MHz}, \mathrm{CDCl}_{3}\right), \delta 14.67(\mathrm{~s}, 1 \mathrm{H},-\mathrm{COOH}), 8.81\left(\mathrm{~s}, 1 \mathrm{H},-\mathrm{C}_{2} \mathrm{H}\right), 7.88(\mathrm{~d}, J=$ $\left.11.9 \mathrm{~Hz}, 1 \mathrm{H},-\mathrm{C}_{5} \mathrm{H}\right), 4.13\left(\mathrm{~s}, 2 \mathrm{H},-\mathrm{CH}_{2} \mathrm{Cl}\right), 4.06-3.99(\mathrm{~m}, 1 \mathrm{H},-\mathrm{NCH}), 3.75\left(\mathrm{~s}, 3 \mathrm{H},-\mathrm{OCH}_{3}\right), 3.74-3.71\left(\mathrm{~m}, 2 \mathrm{H}, 33^{\prime},-\right.$ piperazine-H), 3.53 - $3.48(\mathrm{~m}, 2 \mathrm{H}, 2$, -piperazine-H), 3.39 - $3.35\left(\mathrm{~m}, 2 \mathrm{H}, 2^{\prime}\right.$, -piperazine-H), 3.31 - $3.27\left(\mathrm{~m}, 1 \mathrm{H}, 3^{\prime}\right.$, -piperazine- $\left.\mathrm{H}\right), 1.46-1.40\left(\mathrm{~m}, 2 \mathrm{H},-\mathrm{NCHCH} \underline{2}_{2}\right), 1.26-1.20(\mathrm{~m}, 2 \mathrm{H},-$ $\left.\mathrm{NCHCH}_{2}\right), 1.08-0.96\left(\mathrm{~m}, 3 \mathrm{H}, 3^{\prime}\right.$, -piperazine- $\left.\mathrm{CHCH}_{3}\right)$. HRMS (ESI) m/z 452.1380 [M+H] ${ }^{+}$, calcd. for $\left[\mathrm{C}_{21} \mathrm{H}_{24} \mathrm{ClFN}_{3} \mathrm{O}_{5}\right]^{+}, 452.1389$.

\subsubsection{7-(4-(2-chloroacetyl)piperazin-1-yl)-1-ethyl-6-fluoro-4-oxo-1,4-dihydro-1,8-naphthyri}

dine-3-carboxylic acid (2d) 
Compound 2d, $0.32 \mathrm{~g}$ was obtained, white solid, yield $81 \%,{ }^{1} \mathrm{H}$ NMR $\left(300 \mathrm{MHz}, \mathrm{CDCl}_{3}\right), \delta 14.83(\mathrm{~s}, 1 \mathrm{H}), 8.69(\mathrm{~s}, 1 \mathrm{H}), 8.15(\mathrm{~d}, \mathrm{~J}=12.9 \mathrm{~Hz}, 1 \mathrm{H})$, 4.44 - $4.36(\mathrm{~m}, 2 \mathrm{H}), 4.11(\mathrm{~s}, 2 \mathrm{H}), 3.93$ - $3.85(\mathrm{~m}, 4 \mathrm{H}), 3.83$ - $3.73(\mathrm{~m}, 4 \mathrm{H}), 1.53-1.48(\mathrm{t}, \mathrm{J}=7.1 \mathrm{~Hz}, 3 \mathrm{H}) . \mathrm{HRMS}(\mathrm{ESI}) \mathrm{m} / \mathrm{z} 397.1072[\mathrm{M}+\mathrm{H}]^{+}, \mathrm{calcd}$. for $\left[\mathrm{C}_{17} \mathrm{H}_{19} \mathrm{ClFN}_{4} \mathrm{O}_{4}\right]^{+}, 397.1079$.

\subsubsection{7-(3-(2-chloro-N-methylacetamido)piperidin-1-yl)-1-cyclopropyl-6-fluoro-8-methoxy-4-}

oxo-1,4-dihydroquinoline-3-carboxylic acid (2e)

Compound 2e, $0.41 \mathrm{~g}$ was obtained, white solid, yield 88\%, ${ }^{1} \mathrm{H}$ NMR $\left(300 \mathrm{MHz}, \mathrm{CDCl}_{3}\right), \delta 14.76(\mathrm{~s}, 1 \mathrm{H}), 8.79(\mathrm{dd}, \mathrm{J}=3 \mathrm{~Hz}, 1 \mathrm{H}), 7.86-7.80(\mathrm{~m}$, $1 \mathrm{H}), 4.69-4.62(\mathrm{~m}, 1 \mathrm{H}), 4.07-4.02(\mathrm{~m}, 1 \mathrm{H}), 3.85(\mathrm{~s}, 2 \mathrm{H}), 3.50$ - $3.47(\mathrm{br}, 3 \mathrm{H}), 3.36 \mathrm{n}-3.26(\mathrm{~m}, 1 \mathrm{H}), 3.23-3.20(\mathrm{~m}, 1 \mathrm{H}), 3.05(\mathrm{~s}, 3 \mathrm{H}), 2.07-1.74$ $(\mathrm{m}, 6 \mathrm{H}), 1.27-1.21(\mathrm{~m}, 2 \mathrm{H}), 1.06-0.97(\mathrm{~m}, 2 \mathrm{H})$. HRMS (ESI) m/z 466.1547 [M+H] ${ }^{+}$, calcd. for $\left[\mathrm{C}_{22} \mathrm{H}_{26} \mathrm{ClFN}_{3} \mathrm{O}_{5}\right]^{+}, 466.1545$.

\subsubsection{7-(1-(2-chloroacetyl)octahydro-6H-pyrrolo[3,4-b]pyridin-6-yl)-1-cyclopropyl-6-fluoro-}

8-methoxy-4-oxo-1,4-dihydroquinoline-3-carboxylic acid (2f)

Compound 2f, $0.41 \mathrm{~g}$ was obtained, white solid, yield 86\%, ${ }^{1} \mathrm{H} \mathrm{NMR}\left(300 \mathrm{MHz}, \mathrm{CDCl}_{3}\right), \delta 14.94(\mathrm{~s}, 1 \mathrm{H}), 8.76(\mathrm{~s}, 1 \mathrm{H}), 7.78(\mathrm{~d}, \mathrm{~J}=13.8 \mathrm{~Hz}, 1 \mathrm{H})$, 5.24 - 5.16(m, 1H), 4.62 - $4.68(\mathrm{~m}, 1 \mathrm{H}), 4.15$ - $4.14(\mathrm{~m}, 2 \mathrm{H}), 4.00(\mathrm{~s}, 2 \mathrm{H}), 3.90-3.83(\mathrm{~m}, 2 \mathrm{H}), 3.60(\mathrm{~s}, 3 \mathrm{H}), 3.40-3.28(\mathrm{~m}, 2 \mathrm{H}), 2.41-2.31(\mathrm{~m}, 1 \mathrm{H})$, $1.93-1.89(\mathrm{~m}, 2 \mathrm{H}), 1.68-1.56(\mathrm{~m}, 2 \mathrm{H}), 1.31(\mathrm{br}, 2 \mathrm{H}), 1.12(\mathrm{br}, 2 \mathrm{H}) . \mathrm{HRMS}(\mathrm{ESI}) \mathrm{m} / \mathrm{z} 478.1547\left[\mathrm{M}+\mathrm{H}^{+}\right.$, calcd. for $\left[\mathrm{C}_{23} \mathrm{H}_{26} \mathrm{ClFN}_{3} \mathrm{O}_{5}\right]^{+}, 478.1545$.

\subsubsection{0-(1-(2-chloroacetamido)cyclopropyl)-9-fluoro-3-methyl-7-oxo-2,3-dihydro-7H-}

[1,4]oxazino[2,3,4-ij]quinoline-6-carboxylic acid (2g)

Compound $\mathbf{2 g}, 0.33 \mathrm{~g}$ was obtained, white solid, yield 84\%, ${ }^{1} \mathrm{H}$ NMR $(300 \mathrm{MHz}, \mathrm{CDCl} 3), \delta 14.75(\mathrm{~s}, 1 \mathrm{H}), 8.70(\mathrm{~s}, 1 \mathrm{H}), 7.67(\mathrm{~d}, \mathrm{~J}=10 \mathrm{~Hz}, 1 \mathrm{H})$, $7.36(\mathrm{~s}, 1 \mathrm{H}), 4.64-4.60(\mathrm{~m}, 2 \mathrm{H}), 4.53-4.49(\mathrm{~m}, 1 \mathrm{H}), 3.94(\mathrm{~s}, 2 \mathrm{H}), 1.66(\mathrm{~d}, J=6.6 \mathrm{~Hz}, 3 \mathrm{H}), 1.48-1.41(\mathrm{~m}, 2 \mathrm{H}), 1.38$ - $1.37(\mathrm{~m}, 2 \mathrm{H}) . \mathrm{HRMS}(\mathrm{ESI})$ $\mathrm{m} / \mathrm{z} 395.0807[\mathrm{M}+\mathrm{H}]^{+}$, calcd. for $\left[\mathrm{C}_{18} \mathrm{H}_{17} \mathrm{ClFN}_{2} \mathrm{O}_{5}\right]^{+}, 395.0810$.

\subsection{Synthesis of compound 3a-g}

$0.22 \mathrm{~g}$ (1.1 eq, $0.42 \mathrm{mmol})$ compound 2 and $0.11 \mathrm{~g}$ (2 eq, $0.76 \mathrm{mmol}) \mathrm{K}_{2} \mathrm{CO}_{3}$ in $20 \mathrm{~mL}$ acetonitrile were added to a $50 \mathrm{~mL}$ round bottom flask, stirred at room temperature for $10 \mathrm{~min}$, and then $0.15 \mathrm{~g}$ (1 eq, $0.378 \mathrm{mmol})$ compound $2 \mathrm{a}$ was added, the reaction proceeded at $50{ }^{\circ} \mathrm{C}$ for $24 \mathrm{~h}$. The reaction was quenched and separated on silica gel column eluted by $\mathrm{CH}_{2} \mathrm{Cl}_{2}-\mathrm{MeOH}$ (in a volume ratio 20:1) gave $0.29 \mathrm{~g}$ of $3 a$ in a yield of $81 \%$.

Compound $\mathbf{3 b - g}$ was synthesized in the same way as compound $\mathbf{3 a}$, in the yields of $80-90 \%$.

4.4.1. 1-cyclopropyl-6-fluoro-4-oxo-7-(4-(2-(4,7,10-tris(2-(tert-butoxy)-2-oxoethyl)-1,4,7,10-

tetraazacyclododecan-1-yl)acetyl)piperazin-1-yl)-1,4-dihydroquinoline-3-carboxylic acid (3a)

Compound 3a, $0.29 \mathrm{~g}$ was obtained, light yellow oil, yield $81 \%,{ }^{1} \mathrm{H} \mathrm{NMR}\left(300 \mathrm{MHz}, \mathrm{CDCl}_{3}\right), \delta 8.56(\mathrm{~s}, 1 \mathrm{H}), 7.77(\mathrm{~d}, \mathrm{~J}=13.1 \mathrm{~Hz}, 1 \mathrm{H}), 7.40(\mathrm{br}, 1 \mathrm{H})$, 4.97 (s, 1H), 3.72 (br, 4H), 3.39 (br, 8H), 3.29 (d, J = 7.5 Hz, 4H), 3.06 - 2.75 (m, 16H), 1.40 (s, 27H), 1.30 (s, $1 \mathrm{H}), 1.20$ (s, 1H), 0.99 (s, $2 \mathrm{H}) . \mathrm{HRMS}$ (ESI) $\mathrm{m} / \mathrm{z} 886.5084[\mathrm{M}+\mathrm{H}]^{+}$, calcd. for $\left[\mathrm{C}_{45} \mathrm{H}_{69} \mathrm{FN}_{7} \mathrm{O}_{10}\right]^{+}, 886.5090$.

\subsubsection{1-ethyl-6-fluoro-4-oxo-7-(4-(2-(4,7,10-tris(2-(tert-butoxy)-2-oxoethyl)-1,4,7,10-tetraaz}

acyclododecan-1-yl)acetyl)piperazin-1-yl)-1,4-dihydroquinoline-3-carboxylic acid (3b)

Compound $3 \mathrm{~b}, 0.29 \mathrm{~g}$ was obtained, light yellow oil, yield $88 \%,{ }^{1} \mathrm{H}$ NMR $\left(300 \mathrm{MHz}, \mathrm{CDCl}_{3}\right), \delta 8.48\left(\mathrm{~s}, 1 \mathrm{H},-\mathrm{C}_{2} \mathrm{H}\right), 7.76\left(\mathrm{~d}, \mathrm{~J}=12.8 \mathrm{~Hz}, 1 \mathrm{H},-\mathrm{C}_{5} \mathrm{H}\right.$ ),6.97 (s, 1H, - $\left.\mathrm{C}_{8} \mathrm{H}\right), 4.44-4.35\left(\mathrm{~m}, 2 \mathrm{H},-\mathrm{NCH}_{2}\right), 3.65(\mathrm{br}, 8 \mathrm{H}), 3.36-3.22(\mathrm{~m}, 8 \mathrm{H}), 2.91-2.72(\mathrm{~m}, 16 \mathrm{H}), 1.35(\mathrm{~s}, 30 \mathrm{H},-\mathrm{CH}) . \mathrm{HRMS}(\mathrm{ESI}) \mathrm{m} / \mathrm{z}$ 896.4912 [M+Na] $]^{+}$, calcd. for $\left[\mathrm{C}_{44} \mathrm{H}_{68} \mathrm{FN}_{7} \mathrm{NaO}_{10}\right]^{+}, 896.4909$.

4.4.3. 1-cyclopropyl-6-fluoro-8-methoxy-7-(3-methyl-4-(2-(4,7,10-tris(2-(tert-butoxy)-2-oxoe

thyl)-1,4,7,10-tetraazacyclododecan-1-yl)acetyl)piperazin-1-yl)-4-oxo-1,4-dihydroquinoline-3-

carboxylic acid (3c)

Page $10 / 20$ 
Compound $3 \mathrm{c}, 0.27 \mathrm{~g}$ was obtained, light yellow oil, yield $88 \%,{ }^{1} \mathrm{H} \mathrm{NMR}\left(300 \mathrm{MHz}, \mathrm{CDCl}_{3}\right), \delta 8.60\left(\mathrm{~s}, 1 \mathrm{H},-\mathrm{C}_{2} \mathrm{H}\right), 7.69\left(\mathrm{~d}, J=12.3 \mathrm{~Hz}, 1 \mathrm{H},-\mathrm{C}_{5} \mathrm{H}\right)$,

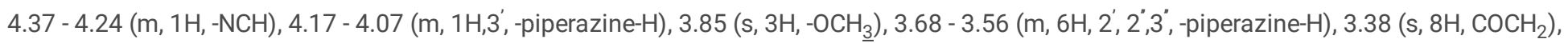
3.2 - 3.0(m, 8H, $\left.-\mathrm{NCH}_{2} \mathrm{CH}_{2} \mathrm{~N}-\right)$, 2.98 - $2.70\left(\mathrm{~m}, 8 \mathrm{H},-\mathrm{NCH}_{2} \mathrm{CH}_{2} \mathrm{~N}-\right), 1.40\left(\mathrm{~s}, 27 \mathrm{H},-\mathrm{CH}_{3}\right), 1.28-1.26\left(\mathrm{~m}, 2 \mathrm{H},-\mathrm{NCH}_{2}\right), 1.06-1.04\left(\mathrm{~m}, 2 \mathrm{H},-\mathrm{NCH}_{2}\right), 0.82(\mathrm{~s}$, $\left.3 \mathrm{H},-\mathrm{CH}_{3}\right)$. HRMS (ESI) m/z $952.5165[\mathrm{M}+\mathrm{Na}]^{+}$, calcd. for $\left[\mathrm{C}_{47} \mathrm{H}_{72} \mathrm{FN}_{7} \mathrm{NaO}_{11}\right]^{+}, 952.5157$.

\subsubsection{1-ethyl-6-fluoro-4-oxo-7-(4-(2-(4,7,10-tris(2-(tert-butoxy)-2-oxoethyl)-1,4,7,10-tetraaza}

cyclododecan-1-yl)acetyl)piperazin-1-yl)-1,4-dihydro-1,8-naphthyridine-3-carboxylic acid (3d)

Compound 3d, $0.30 \mathrm{~g}$ was obtained, light yellow oil, yield 90\%, ${ }^{1} \mathrm{H}$ NMR $\left(300 \mathrm{MHz}, \mathrm{CDCl}_{3}\right), \delta 15.01(\mathrm{~s}, 1 \mathrm{H}), 8.68(\mathrm{~s}, 1 \mathrm{H}), 8.08(\mathrm{~d}, \mathrm{~J}=13.1 \mathrm{~Hz}$, $1 \mathrm{H}), 4.49$ - $4.42(\mathrm{~m}, 2 \mathrm{H}), 4.03$ - $3.77(\mathrm{~m}, 8 \mathrm{H}), 3.71(\mathrm{~s}, 2 \mathrm{H}), 3.59(\mathrm{br}, 4 \mathrm{H}), 3.38(\mathrm{~s}, 2 \mathrm{H}), 3.12$ - $3.10(\mathrm{~m}, 4 \mathrm{H}), 2.96$ - $2.88(\mathrm{~m}, 8 \mathrm{H}), 2.54(\mathrm{br}, 4 \mathrm{H}), 1.46(\mathrm{~s}$, $18 \mathrm{H}), 1.25(\mathrm{~s}, 9 \mathrm{H}), 0.87(\mathrm{t}, J=6.7 \mathrm{~Hz}, 3 \mathrm{H})$. HRMS (ESI) m/z $875.5054[\mathrm{M}+\mathrm{H}]^{+}$, calcd. for $\left[\mathrm{C}_{43} \mathrm{H}_{68} \mathrm{FN}_{8} \mathrm{O}_{10}\right]^{+}, 875.5042$.

4.4.5 1-cyclopropyl-6-fluoro-8-methoxy-7-(3-(N-methyl-2-(4,7,10-tris(2-(tert-butoxy)-2-oxo

ethyl)-1,4,7,10-tetraazacyclododecan-1-yl)acetamido)piperidin-1-yl)-4-oxo-1,4-dihydroquinoline

-3-carboxylic acid (3e)

Compound 3e, $0.26 \mathrm{~g}$ was obtained, light yellow oil, yield $86 \%,{ }^{1} \mathrm{H}$ NMR $\left(300 \mathrm{MHz}, \mathrm{CDCl}_{3}\right), \delta 14.76(\mathrm{~s}, 1 \mathrm{H}), 8.72(\mathrm{t}, \mathrm{J}=2.8 \mathrm{~Hz}, 1 \mathrm{H}), 7.77-7.69$ (m, 1H), $5.25(\mathrm{br}, 1 \mathrm{H}), 4.65$ - $4.54(\mathrm{br}, 1 \mathrm{H}), 4.06$ - $3.99(\mathrm{~m}, 1 \mathrm{H}), 3.76-3.75(\mathrm{~m}, 1 \mathrm{H}), 3.72(\mathrm{~s}, 2 \mathrm{H}), 3.69-3.66(\mathrm{~m}, 1 \mathrm{H}), 3.58(\mathrm{br}, 1 \mathrm{H}), 3.46-3.42(\mathrm{br}$, $2 \mathrm{H}), 3.33(\mathrm{~s}, 3 \mathrm{H}), 3.23(\mathrm{~s}, 2 \mathrm{H}), 3.10(\mathrm{br}, 3 \mathrm{H}), 3.03(\mathrm{~s}, 2 \mathrm{H}), 2.92-2.91(\mathrm{br}, 2 \mathrm{H}), 2.88(\mathrm{~s}, 2 \mathrm{H}), 2.19(\mathrm{br}, 8 \mathrm{H}), 1.84(\mathrm{br}, 8 \mathrm{H}), 1.42-1.40(\mathrm{~m}, 27 \mathrm{H}), 1.24-$ $1.23(\mathrm{~m}, 2 \mathrm{H}), 1.19(\mathrm{br}, 2 \mathrm{H})$. HRMS (ESI) m/z $944.5515[\mathrm{M}+\mathrm{H}]^{+}$, calcd. for $\left[\mathrm{C}_{48} \mathrm{H}_{75} \mathrm{FN}_{7} \mathrm{O}_{11}\right]^{+}, 944.5509$.

4.4.6 1-cyclopropyl-6-fluoro-8-methoxy-4-oxo-7-(1-(2-(4,7,10-tris(2-(tert-butoxy)-2-oxoethyl)-

1,4,7,10-tetraazacyclododecan-1-yl)acetyl)octahydro-6H-pyrrolo[3,4-b]pyridin-6-yl)-1,4-dihydroquinoline-3-carboxylic acid (3f)

Compound $\mathbf{3 f}, 0.30 \mathrm{~g}$ was obtained, light yellow oil, yield $90 \%,{ }^{1} \mathrm{H}$ NMR $\left(300 \mathrm{MHz}, \mathrm{CDCl}_{3}\right), \delta 8.74(\mathrm{~d}, \mathrm{~J}=4.2 \mathrm{~Hz}, 1 \mathrm{H}), 7.77-7.72(\mathrm{~m}, 1 \mathrm{H}), 5.18-$ $5.10(\mathrm{~m}, 1 \mathrm{H}), 4.29-4.22(\mathrm{~m}, 1 \mathrm{H}), 4.00(\mathrm{br}, 3 \mathrm{H}), 3.69(\mathrm{~s}, 2 \mathrm{H}), 3.58(\mathrm{~s}, 2 \mathrm{H}), 3.55(\mathrm{~s}, 2 \mathrm{H}), 3.35(\mathrm{~s}, 2 \mathrm{H}), 3.28(\mathrm{br}, 2 \mathrm{H}), 3.12-3.09(\mathrm{~m}, 2 \mathrm{H}), 3.09-3.00$ $(\mathrm{m}, 2 \mathrm{H}), 2.44-2.00(\mathrm{~m}, 16 \mathrm{H}), 2.71-1.70(\mathrm{br}, 1 \mathrm{H}), 1.85-1.81(\mathrm{~m}, 4 \mathrm{H}), 1.45-1.43(\mathrm{~m}, 27 \mathrm{H}), 1.13-1.06(\mathrm{~m}, 2 \mathrm{H}), 0.83-0.77(\mathrm{~m}, 2 \mathrm{H}) . \mathrm{HRMS}(\mathrm{ESI})$ $\mathrm{m} / \mathrm{z} 956.5515[\mathrm{M}+\mathrm{H}]^{+}$, calcd. for $\left[\mathrm{C}_{49} \mathrm{H}_{75} \mathrm{FN}_{7} \mathrm{O}_{11}\right]^{+}, 956.5509$.

4.4.7 9-fluoro-3-methyl-7-oxo-10-(1-(2-(4,7,10-tris(2-(tert-butoxy)-2-oxoethyl)-1,4,7,10-

tetraazacyclododecan-1-yl)acetamido)cyclopropyl)-2,3-dihydro-7H-[1,4]oxazino[2,3,4-ij]quinoline-6-carboxylic acid (3g)

Compound $\mathbf{3 g}, 0.27 \mathrm{~g}$ was obtained, light yellow oil, yield 82\%, ${ }^{1} \mathrm{H}$ NMR $(300 \mathrm{MHz}, \mathrm{CDCl} 3), \delta 14.86(\mathrm{~s}, 1 \mathrm{H}), 9.67(\mathrm{~s}, 1 \mathrm{H}), 8.64(\mathrm{~d}, \mathrm{~J}=3.6 \mathrm{~Hz}, 1 \mathrm{H})$, $7.60(\mathrm{~d}, J=10.1 \mathrm{~Hz}, 1 \mathrm{H}), 4.89-4.83(\mathrm{~m}, 1 \mathrm{H}), 4.56-4.52(\mathrm{~m}, 1 \mathrm{H}), 3.48$ - $3.45(\mathrm{~m}, 1 \mathrm{H}) 3.38(\mathrm{~s}, 2 \mathrm{H}), 3.36(\mathrm{~s}, 2 \mathrm{H}), 3.31(\mathrm{~s}, 2 \mathrm{H}), 3.28(\mathrm{~s}, 2 \mathrm{H}), 2.87(\mathrm{br}$, 8H), 2.77 - $2.69(\mathrm{~m}, 8 \mathrm{H}), 1.45-1.43(\mathrm{~m}, 27 \mathrm{H}), 1.32(\mathrm{br}, 1 \mathrm{H}), 1.24(\mathrm{br}, 3 \mathrm{H}), 1.08(\mathrm{br}, 2 \mathrm{H}), 0.89-0.85(\mathrm{~m}, 1 \mathrm{H}) . \mathrm{HRMS}(\mathrm{ESI}) \mathrm{m} / \mathrm{z} 873.4769[\mathrm{M}+\mathrm{H}]^{+}$, calcd. for $\left[\mathrm{C}_{44} \mathrm{H}_{66} \mathrm{FN}_{6} \mathrm{O}_{11}\right]^{+}, 873.4774$.

\subsection{Synthesis of compound $4 a-g$}

$0.2 \mathrm{~g}$ ( 1 eq, $0.23 \mathrm{mmol}$ ) 3a was dissolved in $10 \mathrm{~mL}$ of TFA and stirred for about 40 - $48 \mathrm{~h}$ to remove the tert-butyl groups on the carboxylic acids in D03A. Then the excess TFA was removed under vacuum. The $0.2 \mathrm{~g}$ final de-protected product $4 \mathrm{a}$ was precipitated with cold ether, filtered and dried under vacuum, in the yield of $80 \%$.

Compound $\mathbf{4 b - g}$ was synthesized in the same way as compound $\mathbf{4 a}$, in the yields of $70-90 \%$.

4.5.1 2,2',2"-(10-(2-(4-(3-carboxy-1-cyclopropyl-6-fluoro-4-oxo-1,4-dihydroquinolin-7-yl)pip

erazin-1-yl)-2-oxoethyl)-1,4,7,10-tetraazacyclododecane-1,4,7-triyl)triacetic acid (4a)

Compound 4a, $0.13 \mathrm{~g}$ was obtained, powdery light yellow solid, yield $80 \%,{ }^{1} \mathrm{H}$ NMR $\left(300 \mathrm{MHz}, \mathrm{CD}_{3} \mathrm{OD}\right), \delta 8.73(\mathrm{~s}, 1 \mathrm{H}), 7.86(\mathrm{~d}, \mathrm{~J}=13.1 \mathrm{~Hz}, 1 \mathrm{H})$, 7.54 (br, 1H), 4.16 (s, 1H), 3.78 - 3.65 (br, 16H), 3.46 - 3.31 (br, 16H), 1.38 (br, 2H), 1.20 (br, 2H). HRMS (ESI) m/z 756.2663 [M+K] $]^{+}$calcd. for $\left[\mathrm{C}_{33} \mathrm{H}_{44} \mathrm{FKN}_{7} \mathrm{O}_{10}\right]^{+}, 756.2771$. 
4.5.2. 2,2'2"-(10-(2-(4-(3-carboxy-1-ethyl-6-fluoro-4-oxo-1,4-dihydroquinolin-7-yl)piperazin

-1-yl)-2-oxoethyl)-1,4,7,10-tetraazacyclododecane-1,4,7-triyl)triacetic acid (4b)

Compound 4b, $0.12 \mathrm{~g}$ was obtained, powdery light yellow solid, yield 75\%, ${ }^{1} \mathrm{H}$ NMR $\left(300 \mathrm{MHz}, \mathrm{CD}_{3} \mathrm{OD}\right), \delta 8.79(\mathrm{~s}, 1 \mathrm{H}), 7.92(\mathrm{brs}, 1 \mathrm{H}), 7.14(\mathrm{br}$, $1 \mathrm{H}), 4.16(\mathrm{br}, 2 \mathrm{H}), 3.76(\mathrm{br}, 16 \mathrm{H}), 3.31(\mathrm{br}, 16 \mathrm{H}), 1.52(\mathrm{br}, 3 \mathrm{H}) . \mathrm{HRMS}(\mathrm{ESI}) \mathrm{m} / \mathrm{z} 744.2667[\mathrm{M}+\mathrm{K}]^{+}, \mathrm{calcd}_{.}$for $\left[\mathrm{C}_{32} \mathrm{H}_{44} \mathrm{FKN}_{7} \mathrm{O}_{10}\right]^{+}, 744.2771$.

4.5.3. 2,2',2"-(10-(2-(4-(3-carboxy-1-cyclopropyl-6-fluoro-8-methoxy-4-oxo-1,4-dihydroquinol

in-7-yl)-2-methylpiperazin-1-yl)-2-oxoethyl)-1,4,7,10-tetraazacyclododecane-1,4,7-triyl)triacetic acid (4c)

Compound 4c, $0.13 \mathrm{~g}$ was obtained, powdery light yellow solid, yield 79\%, ${ }^{1} \mathrm{H}$ NMR $(400 \mathrm{MHz}, \mathrm{DMSO}) \delta 14.87(\mathrm{~s}, 1 \mathrm{H}), 8.69(\mathrm{~s}, 1 \mathrm{H}), 7.72(\mathrm{~d}, \mathrm{~J}=$ $11.9 \mathrm{~Hz}, 1 \mathrm{H}), 4.62$ - 4.60 (m, 1H), 4.16 (brs, 3H), 4.07 (br, 2H), 3.73 (br, 4H) 3.54 (br, 1H), 3.45 (brs, $8 \mathrm{H}), 3.37$ - 3.34 (m, $4 \mathrm{H}), 3.17$ (s, $10 \mathrm{H}), 3.03$ (s, 2H), 1.30 - 1.28 (m, 2H), 1.13 - 1.12 (m, 2H), 1.02 (brs, 3H). ${ }^{13} \mathrm{C}$ NMR (101 MHz, DMSO) $\delta 176.38,176.36,172.87,165.70,158.57,158.25$, $150.70,146.23,139.70,139.59,134.23,121.37,118.38,115.41,106.77,64.96,63.72,54.75,54.71,54.51,54.05,53.09,52.94,51.65,50.95$,

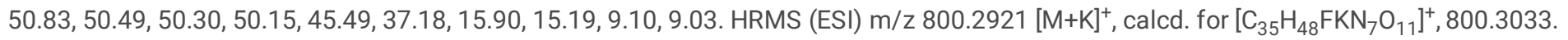

4.5.4. 2,2',2"-(10-(2-(4-(6-carboxy-8-ethyl-3-fluoro-5-oxo-5,8-dihydro-1,8-naphthyridin-2-yl)

piperazin-1-yl)-2-oxoethyl)-1,4,7,10-tetraazacyclododecane-1,4,7-triyl)triacetic acid (4d)

Compound 4d, $0.13 \mathrm{~g}$ was obtained, powdery light yellow solid, yield 81\%, ${ }^{1} \mathrm{H}$ NMR $\left(300 \mathrm{MHz}, \mathrm{CD}_{3} \mathrm{OD}\right), \delta 8.82(\mathrm{~s}, 1 \mathrm{H}), 8.03(\mathrm{~d}, \mathrm{~J}=11.1 \mathrm{~Hz}, 1 \mathrm{H})$, 4.49 (br, 2H), 4.12 (br, 4H), 3.92 (br, 4H), 3.73 (br, 8H), 3.48 - 3.41(m, 8H), 3.25 - 3.14 (m, 8H), 1.46 (br, 3H). HRMS (ESI) m/z 745.2623 [M+K] , calcd. for $\left[\mathrm{C}_{31} \mathrm{H}_{43} \mathrm{FKN}_{8} \mathrm{O}_{10}\right]^{+}, 745.2723$.

4.5.1.5. 2,2',2"-(10-(2-((1-(3-carboxy-1-cyclopropyl-6-fluoro-8-methoxy-4-oxo-1,4-dihydroquin

olin-7-yl)piperidin-3-yl)(methyl)amino)-2-oxoethyl)-1,4,7,10-tetraazacyclododecane-1,4,7-triyl)triacetic acid (4e)

Compound 4e, $0.12 \mathrm{~g}$ was obtained, powdery light yellow solid, yield 73\%, ${ }^{1} \mathrm{H}$ NMR $\left(300 \mathrm{MHz}, \mathrm{CD}_{3} \mathrm{OD}\right), \delta 8.76(\mathrm{~d}, \mathrm{~J}=2.0 \mathrm{~Hz}, 1 \mathrm{H}), 7.71-7.63(\mathrm{~m}$, $1 \mathrm{H}), 4.50(\mathrm{br}, 1 \mathrm{H}), 4.14(\mathrm{~s}, 3 \mathrm{H}), 4.02-3.99(\mathrm{~m}, 1 \mathrm{H}), 3.81(\mathrm{~s}, 2 \mathrm{H}), 3.75(\mathrm{~s}, 2 \mathrm{H}), 3.71(\mathrm{~s}, 2 \mathrm{H}), 3.61-3.32(\mathrm{~m}, 16 \mathrm{H}), 3.21(\mathrm{br}, 2 \mathrm{H}), 3.01(\mathrm{br}, 2 \mathrm{H}), 2.93(\mathrm{~s}$, $3 \mathrm{H}), 1.84(\mathrm{br}, 4 \mathrm{H}), 1.26-1.25(\mathrm{~m}, 1 \mathrm{H}), 1.19-1.15(\mathrm{~m}, 2 \mathrm{H}), 1.13-1.10(\mathrm{~m}, 1 \mathrm{H}), 1.02-0.99(\mathrm{~m}, 2 \mathrm{H}) . \mathrm{HRMS}(\mathrm{ESI}) \mathrm{m} / \mathrm{z} 814.3093[\mathrm{M}+\mathrm{K}]^{+}, \mathrm{calcd} . \mathrm{for}$ $\left[\mathrm{C}_{36} \mathrm{H}_{50} \mathrm{FKN}_{7} \mathrm{O}_{11}\right]^{+}, 814.3189$.

4.5.6. 2,2',2"-(10-(2-(6-(3-carboxy-1-cyclopropyl-6-fluoro-8-methoxy-4-oxo-1,4-dihydroquino

lin-7-yl)octahydro-1H-pyrrolo[3,4-b]pyridin-1-yl)-2-oxoethyl)-1,4,7,10-tetraazacyclododecane-1,4,7-triyl)triacetic acid (4f)

Compound 4f, $0.14 \mathrm{~g}$ was obtained, powdery light yellow solid, yield 85\%, ${ }^{1} \mathrm{H}$ NMR $\left(300 \mathrm{MHz}, \mathrm{CD}_{3} \mathrm{OD}\right), \delta 8.80(\mathrm{~s}, 1 \mathrm{H}), 7.69-7.64(\mathrm{~m}, 1 \mathrm{H}), 4.56-$ $4.51(\mathrm{~m}, 1 \mathrm{H}), 4.15(\mathrm{br}, 3 \mathrm{H}), 3.97-3.90(\mathrm{~m}, 8 \mathrm{H}), 3.65(\mathrm{br}, 4 \mathrm{H}), 3.52$ - $3.45(\mathrm{~m}, 8 \mathrm{H}), 3.38-3.35(\mathrm{~m}, 2 \mathrm{H}), 3.08(\mathrm{br}, 4 \mathrm{H}), 2.87(\mathrm{br}, 1 \mathrm{H}), 2.35(\mathrm{br}, 1 \mathrm{H})$, 1.88 (br, 4H), $1.64-1.59(\mathrm{~m}, 2 \mathrm{H}), 1.34-1.30(\mathrm{~m}, 2 \mathrm{H}), 1.21-1.16(\mathrm{~m}, 2 \mathrm{H}), 1.10-1.06(\mathrm{~m}, 1 \mathrm{H}), 0.93-0.87$ (m, $1 \mathrm{H}) . \mathrm{HRMS}(\mathrm{ESI}) \mathrm{m} / \mathrm{z} 826.3093$ $[\mathrm{M}+\mathrm{K}]^{+}$, calcd. for $\left[\mathrm{C}_{37} \mathrm{H}_{50} \mathrm{FKN}_{7} \mathrm{O}_{11}\right]^{+}, 826.3189$.

4.5.7. 2,2',2"-(10-(2-((1-(6-carboxy-9-fluoro-3-methyl-7-oxo-2,3-dihydro-7H-[1,4]oxazino[2,3

,4-ij]quinolin-10-yl)cyclopropyl)amino)-2-oxoethyl)-1,4,7,10-tetraazacyclododecane-1,4,7-triyl)triacetic acid (4g)

Compound $\mathbf{4 g}, 0.13 \mathrm{~g}$ was obtained, powdery light yellow solid, yield $81 \%,{ }^{1} \mathrm{H}$ NMR $\left(300 \mathrm{MHz}, \mathrm{CD}_{3} \mathrm{OD}\right), \delta 8.79(\mathrm{~s}, 1 \mathrm{H}), 7.91(\mathrm{~s}, 1 \mathrm{H}), 7.53(\mathrm{~d}, \mathrm{~J}=$ $10 \mathrm{~Hz}, 1 \mathrm{H}), 4.75(\mathrm{br}, 1 \mathrm{H}), 4.56(\mathrm{br}, 1 \mathrm{H}), 4.47(\mathrm{br}, 1 \mathrm{H}), 3.49$ - $3.40(\mathrm{~m}, 8 \mathrm{H}), 3.32$ - $3.17(\mathrm{~m}, 8 \mathrm{H}), 3.21-3.15(\mathrm{~m}, 8 \mathrm{H}), 1.33(\mathrm{br}, 2 \mathrm{H}), 1.26(\mathrm{~s}, 3 \mathrm{H}), 1.17$ $1.10(\mathrm{~m}, 2 \mathrm{H})$. HRMS (ESI) m/z $705.2880[\mathrm{M}+\mathrm{H}]^{+}$, calcd. for $\left[\mathrm{C}_{32} \mathrm{H}_{42} \mathrm{FN}_{6} \mathrm{O}_{11}\right]^{+}, 705.2896 . \mathrm{HRMS}(\mathrm{ESI}) \mathrm{m} / \mathrm{z} 743.2354[\mathrm{M}+\mathrm{K}]^{+}, \mathrm{calcd} . \mathrm{for}$ $\left[\mathrm{C}_{32} \mathrm{H}_{41} \mathrm{FKN}_{6} \mathrm{O}_{11}\right]^{+}, 743.2454$.

\subsection{Biological activity}

\subsection{1. $M I C$ and $M B C$ determinations in vitro}

MRSA (clinical isolates), P. aeruginosa (clinical isolates) and E. coli (clinical isolates) were used in this experiment, which was provided by the People's Liberation Army 304 Hospital.

Page $12 / 20$ 
The antimicrobial activities of these newly synthesized compounds were evaluated in vitro against MRSA, P.aeruginosa and E.coli, which are the representative of Gram-positive bacteria strains and Gram-negative bacterial strains. The standard two folds serial dilution method in 96 well micro-test plates was employed according to the National Committee for Clinical Laboratory Standards (NCCLS) [43]. MRSA interaction with compound $\mathbf{4 c}$, as an example of screening method, was described as following in detail. The experiments were performed in 96 -well flat bottom plates in a sterile workbench. Firstly a rough screening outlined an antibacterial concentration range, then a series of $\mathbf{4 c}$ solutions in different concentrations were prepared by two folds serial dilution method respectively. The final concentration of the MRSA, logarithmic growth phase bacteria, was diluted to $10^{6}$ colony-forming units $/ \mathrm{mL}(\mathrm{CFU} / \mathrm{mL})$. Then, $180 \mu \mathrm{L}$ of $\mathbf{4 c}$ solution in the above serial different concentrations and $20 \mu \mathrm{L}$ of MRSA were added to each well and mixed, respectively. Three sets of independent experiments were performed. Finally, the samples of plates were incubated in the dark at $37^{\circ} \mathrm{C}$ and $\mathrm{CFU}$ was evaluated after $24 \mathrm{~h}$. The turbidity degree of the bacterial solution was eye observed. The minimum inhibitory concentration (MIC) is defined as the first drug concentration with reduced turbidity, clear and transparent solution. Then, $100 \mu \mathrm{L}$ of the different gradient concentration drug and bacteria mixed solution in the 96 -well micro-test plate were separately aspirated, and the mixture was uniformly coated on LB solid medium, and further incubated at $37{ }^{\circ} \mathrm{C}$ in the dark, and evaluated after $24 \mathrm{~h}$. The number of colonies less than or equal to 5 is used as the minimum bactericidal concentration (MBC).

\subsubsection{The ADMET prediction}

The ADMET (absorption, distribution, metabolism, excretion and toxicity) properties of the synthesized compounds were calculated using insilico tools and web-based applications. Hydrogen bond donor (HBD), hydrogen bond acceptor (HBA), number of rotatable bonds (RBN), water accessible surface area (ASA), rule of five and total polar surface area (ASA_P) were calculated by MOE ver 2008.10 (Chemical Computing Group, Montreal, Canada). While, CPY2D6 inhibition (CYP2D6), Plasma protein binding (PPB), Carcinogenicity Mouse (Carcino_M) and hERG inhibition (hERG) were calculated via PreADMET ver 2.0 (Yonsei University, Seoul, Korea, https://preadmet.bmdrc.kr).

\subsubsection{Docking study}

A molecular docking study was performed using Glide modules of Schrödinger suite 2009 (Schrödinger LLC, NewYork) [44]. The X-ray structure of DNA gyrase complex with ciprofloxacin (PDB ID: 2XCT) and DNA topoisomerase IV with a novel fluoroquinolone (PDB ID: 4KPF) were retrieved from the protein data bank (PDB). Before docking, initial proteins were refined using protein preparation wizard to assign bond orders, add hydrogen atoms, treat metal ions, predict side chains and remove all water molecules $[45,46]$. Subsequently, the proteins were optimized by reorienting the hydrogen bond network and energy minimized using OPLS2005 force field [47]. Receptor grid was generated around the co-crystallized ligands with the center coordinates 2 XCT $(x=2.6951, y=44.4391, z=68.1055)$ and $4 \mathrm{KPF}(x=-40.3970, y=$ 78.2317, $z=-10.9810)$, respectively. The size of the grid box was set to $20 \AA$ and Vander Waals radius of receptor atoms was scaled to 1.00 with partial atomic charge less than 0.25 . All the synthesized quinolones were constructed using the Maestro workspace build panel and prepared using the Ligprep application to generate variations on the ionization states, tautomers, stereochemistry and ring conformations. Then the molecular geometry of the structures was energy minimized using the OPLS2005 force field. With the default parameters, docking calculations were performed using Standard Precision (SP) mode [48]. Docking score, glide energy and glide ligand efficiency were together used to determine the best binding pose for each ligand. The Pose Viewer panel [49] was applied for visualization and distance measurement of the $\mathrm{H}$-bond contacts between the ligands and active site residues of model proteins

\subsubsection{Atomic force microscope assay of sample preparation}

The prepared bacterial suspension was diluted to $10^{7} \mathrm{CFU} / \mathrm{mL}$ with LB liquid medium and was mixed with the drug solution in an equal volume so that the concentration of $\mathbf{1 c}$ and $\mathbf{4 c}$ was $10 \mu \mathrm{mol} / \mathrm{L}$ respectively. The mixing solution was incubated at $37^{\circ} \mathrm{C}$ for $30 \mathrm{~min}$. The blank control group was also established at the same time. After that, the sample was centrifuged at 9000 RPM for 5 min and the supernatant was discarded. The precipitate was washed twice with physiological saline and centrifuged at 9000 RPM for 5 min. Finally, the bacterial samples were dropped onto the surface of the mica plate (about $0.5 \mathrm{~cm}^{2}$ ), dried naturally at ambient temperature, then scanned by an atomic force microscope (Veeco Multi Mode 8/B0021, Veeco German).

\subsubsection{Cytotoxicity assay on the L-02, A549 and MCF-7 cells.}

According to reports in the literature $[50,51]$, it is very meaningful to study compound $\mathbf{4 c}$ for the toxicity of human normal liver cells (L-02) and tumor cells (A549 and MCF-7). Here, L-02 cell was used as an example of the cytotoxicity assay in vitro [52]. L-02 cells in the log phase at the density $5 \times 10^{3}$ cells/well were collected and cultured in complete DMEM at $37^{\circ} \mathrm{C}$ under $5 \% \mathrm{CO}_{2}$ incubator for $24 \mathrm{~h}$. After different concentrations of $1 \mathrm{c}$ and $\mathbf{4 c}$ were added to each well, L-02 cells were cultured for $24 \mathrm{~h}$ at $37^{\circ} \mathrm{C}$ under $5 \% \mathrm{CO}_{2}$. Then the medium was poured off before $100 \mu \mathrm{L}$ of serum-free medium and $20 \mu \mathrm{L}$ of MTS were added to each well, and the mixture was incubated for $1 \mathrm{~h}$ at $37^{\circ} \mathrm{C}$. Finally, the cell viability was measured by a microplate reader (Thermo, Varioskan Flash 3001, USA) at a wavelength of $490 \mathrm{~nm}$, and calculated cell survival rate according to the following formula : 
Cell survival rate $(\%)=\left(O D_{\text {test }}-O D_{\text {blank }}\right) /\left(O D_{\text {control }}-O D_{\text {blank }}\right) \times 100 \%$

\section{Declarations}

\section{Competing interests}

The authors declare that they have no competing interests.

\section{Acknowledgments}

The authors gratefully acknowledge Chinese Academy of Medical Sciences \& Peking Union Medical College information technology center for affording the Schrödinger suite 2009 and MOE ver 2008.10 software. This study was supported by the national Mega-project for Innovative Drugs (2019ZX09721001-006-001/2018ZX09711001-005-018), the CAMS Innovation Fund for Medical Sciences (2019-I2M-1-005/2017-I2M3-021) and the Tianjin Key Technology R\&D Program (20YFZCSY00570).

\section{References}

1. Feng LS, Liu ML, Wang S, Chai Y, Lv K, Shan GZ, et al. Synthesis of naphthyridone derivatives containing 8-alkoxyimino-1,6dizaspiro[3.4]octane scaffolds. Tetrahedron. 2011;67(43):8264-70.

2. Andriole VT. The quinolones: past, present, and future. Clinical Infectious Diseases. 2005;41 Suppl 2:S113.

3. Mitscher LA. Bacterial topoisomerase inhibitors: quinolone and pyridone antibacterial agents. Chem Rev. 2005;105(2):559-92.

4. Zhang GF, Zhang S, Pan B, Liu X, Feng LS. 4-Quinolone derivatives and their activities against Gram positive pathogens. Eur J Med Chem. 2018;143:710-23.

5. Wan ZL, Yun C, Liu ML, Guo HY, Sun LY. Synthesis and in vitro antibacterial activity of 7-(4-alkoxyimino-3-methyl-3-methylaminopiperidin-1yl)quinolones. Acta Pharm Sin. 2010;45(7):860-8.

6. Hu YQ, Zhang S, Xu Z, Lv ZS, Liu ML, Feng LS. 4-Quinolone hybrids and their antibacterial activities. Eur J Med Chem. 2017;13(1):335-45.

7. Arcieri G, Griffith E, Gruenwaldt G, Heyd A, O'Brien B, Screen P, et al. A survey of clinical experience with ciprofloxacin, a new quinolone antimicrobial. J Clin Pharmacol. 2015;28(2):179-89.

8. Chu DT. Section Review Anti-infectives: The future role of quinolones. Expert Opin Ther Pat. 2008;6(8):711-37.

9. Dalhoff A. Antiviral, antifungal, and antiparasitic activities of fluoroquinolones optimized for treatment of bacterial infections: a puzzling paradox or a logical consequence of their mode of action? Eur J Clin Microbiol Infect Dis. 2015;34(4):661-8.

10. Florindo C, Costa A, Matos C, Nunes SL, Matias AN, Duarte CMM, et al. Novel organic salts based on fluoroquinolone drugs: Synthesis, bioavailability and toxicological profiles. Int J Pharm. 2014;469(1):179-89.

11. Assali M, Joulani M, Awwad R, Assad M, Almasri M, Kittana N, et al. Facile synthesis of ciprofloxacin prodrug analogues to improve its water solubility and antibacterial activity. Chemistryselect. 2016;1(6):1132-5.

12. Wang Y, He J, Liao M, Hu M, Li W, Ouyang H, et al. An overview of Sirtuins as potential therapeutic target: Structure, function and modulators. Eur J Med Chem. 2019;161:48-77.

13. Chu XM, Wang C, Liu W, Liang LL, Gong KK, Zhao CY, et al. Quinoline and quinolone dimers and their biological activities: An overview. Eur J Med Chem. 2019;161:101-17.

14. Katritzky AR, Munawar MA, Kovacs J, Khelashvili L. Synthesis of amino acid derivatives of quinolone antibiotics. Org Biomol Chem. 2009;7(11):2359-62.

15. Panda SS, Detistov OS, Girgis AS, Mohapatra PP, Samir A, Katritzky AR. Synthesis and molecular modeling of antimicrobial active fluoroquinolone-pyrazine conjugates with amino acid linkers. Bioorg Med Chem Lett. 2016;26(9):2198-205.

16. Dong TA. Synthesis and biological testing of glycosylated fluoroquinolone antibiotics. Dissertations \& Theses - Gradworks. 2012. 
17. Varvara P, Valery B, Mariana H, Sima Y, Timor B. Design, synthesis, and evaluation of novel fluoroquinolone-aminoglycoside hybrid antibiotics. J Med Chem. 2009;52(8):2243-54.

18. Zhu Q, Qiu F, Zhu B, Zhu X. Hyperbranched polymers for bioimaging. Rsc Adv. 2013;3(7):2071-83.

19. Patil R, Gangalum PR, Wagner S, Portilla-Arias J, Ding H, Rekechenetskiy A, et al. Curcumin targeted, polymalic acid-based MRI contrast agent for the detection of $A \beta$ plaques in Alzheimer's disease. Macromol Biosci. 2015;15(9):1212-7.

20. Bort G, Catoen S, Borderies H, Kebsi A, Ballet S, Louin G, et al. Gadolinium-based contrast agents targeted to amyloid aggregates for the early diagnosis of Alzheimer's disease by MRI. Eur J Med Chem. 2014;87:843-61.

21. Mikawa M, Kato H, Okumura M, Narazaki M, Kanazawa Y, Shinohara H. Paramagnetic water-soluble metalofullerenes having the highest relaxivit for MRI contrast agents. Bioconjug Chem. 2001;12(4):510-4.

22. Wickham JR, Rice CV. Solid-state NMR studies of bacterial lipoteichoic acid adsorption on different surfaces. Solid State Nucl Magn Reson. 2008;34(3):154-61.

23. Chen W, Hao L. Intracellular nitrite accumulation: The cause of growth inhibition of Microcystis aeruginosa exposure to high nitrite level. Phycol Res. 2015;63(3):197-201.

24. Christopher W, Andreas P. Teichoic acids and related cell-wall glycopolymers in Gram-positive physiology and host interactions. Nat Rev Microbiol. 2008;6(4):276-87.

25. Nikola M, Andrej P, Marjana N, Tom S. Cluster-based molecular docking study for in silico identification of novel 6-fluoroquinolones as potential inhibitors against Mycobacterium tuberculosis. J Comput Chem. 2013;34(9):790-801.

26. Bax BD, Chan PF, Eggleston DS, Andrew F, Gentry DR, Fabrice G, et al. Type IIA topoisomerase inhibition by a new class of antibacterial agents. Nature. 2010;466(7309):935-40.

27. Labute P. A widely applicable set of descriptors. Journal of Molecular Graphics \& Modelling. 2000;18(4-5):464-77.

28. Soliman DH, Abdelrahman MA, Gomaa MS, Elasser MM, Abdel-Aziz MM, Salama I. Design, synthesis and 2D QSAR study of novel pyridine and quinolone hydrazone derivatives as potential antimicrobial and antitubercular agents. Eur J Med Chem. 2017;138:698.

29. Zhang SN, Li XZ, Yang XY. Drug-likeness prediction of chemical constituents isolated from Chinese materia medica Ciwujia. J Ethnopharmacol. 2017;198:131-8.

30. Patrick. An Introduction to Medicinal Chemistry 3e. Science \& Mathematics. 2009;6(1):96-101.

31. Davies BJ, Coller JK, Somogyi AA, Milne RW, Sallustio BC. CYP2B6, CYP2D6, and CYP3A4 catalyze the primary oxidative metabolism of perhexiline enantiomers by human liver microsomes. Drug Metab Dispos. 2007;35(1):128-38.

32. Cho DY, Bae SH, Lee JK, Kim YW, Kim BT, Bae SK. Selective inhibition of cytochrome P450 2D6 by Sarpogrelate and its active metabolite, M-1, in human liver microsomes. Drug Metab Dispos. 2014;42(1):33-9.

33. Minovski N, Perdih A, Novic M, Solmajer T. Cluster-based molecular docking study for in silico identification of novel 6-fluoroquinolones as potential inhibitors against Mycobacterium tuberculosis. J Comput Chem. 2013;34(9):790-801.

34. Bax BD, Chan PF, Eggleston DS, Fosberry A, Gentry DR, Gorrec F, et al. Type IIA topoisomerase inhibition by a new class of antibacterial agents. Nature. 2010;466(7309):935-40.

35. Laponogov I, Pan XS, Veselkov DA, Cirz RT, Wagman A, Moser HE, et al. Exploring the active site of the Streptococcus pneumoniae topoisomerase IV-DNA cleavage complex with novel 7,8-bridged fluoroquinolones. Open Biol. 2016;6(9):160157.

36. Giulio R, Alberto DR, Gianluca D, Miriam S. Fast and accurate predictions of binding free energies using MM-PBSA and MM-GBSA. J Comput Chem. 2010;31(4):797-810.

37. Andrew LH, Keserü GM, Leeson PD, Rees DC, Reynolds CH. The role of ligand efficiency metrics in drug discovery. Nat rev Drug discov. 2014;13(2):105-21. 
38. Mentese MY, Bayrak H, Uygun Y, Mermer A, Ulker S, Karaoglu SA, et al. Microwave assisted synthesis of some hybrid molecules derived from norfloxacin and investigation of their biological activities. Eur J Med Chem. 2013;67(17):230-42.

39. Xu Z, Gao Y, Meng S, Yang B, Pang L, Wang C, et al. Mechanism and in vivo evaluation: Photodynamic antibacterial chemotherapy of lysine-porphyrin conjugate. Front in Microbiol. 2016;7:242.

40. Eaton P, Fernandes JC, Pereira E, Pintado ME, Malcata FX. Atomic force microscopy study of the antibacterial effects of chitosans on Escherichia coli and Staphylococcus aureus. Ultramicroscopy. 2008;108(10):1128-34.

41. Perry CC, Weatherly M, Beale T, Randriamahefa A. Atomic force microscopy study of the antimicrobial activity of aqueous garlic versus ampicillin against Escherichia coli and Staphylococcus aureus. J Sci Food Agric. 2010;89(6):958-64.

42. Sahu K, Bansal H, Mukherjee C, Sharma M, Gupta PK. Atomic force microscopic study on morphological alterations induced by photodynamic action of Toluidine Blue 0 in Staphylococcus aureus and Escherichia coli. J Photochem Photobiol B. 2009;96(1):9-16.

43. Tiwari SV, Seijas JA, Vazquez-Tato MP, Sarkate AP, Karnik KS, Apg N. lonic liquid-promoted synthesis of novel chromone-pyrimidine coupled derivatives, antimicrobial analysis, enzyme assay, docking study and toxicity study. Molecules. 2018;23(2):440.

44. Friesner RA, Murphy RB, Repasky MP, Frye LL, Greenwood JR, Halgren TA, et al. Extra precision glide: docking and scoring incorporating a model of hydrophobic enclosure for protein-ligand complexes. J Med Chem. 2006;49(21):6177-96.

45. Sastry GM, Adzhigirey M, Day T, Annabhimoju R, Sherman W. Protein and ligand preparation: parameters, protocols, and influence on virtual screening enrichments. J Comput Aided Mol Des. 2013;27(3):221-34.

46. Shaik JB, Palaka BK, Penumala M, Kotapati KV, Devineni SR, Eadlapalli S, et al. Synthesis, pharmacological assessment, molecular modeling and in silico studies of fused tricyclic coumarin derivatives as a new family of multifunctional anti-Alzheimer agents. Eur $\mathrm{J}$ Med Chem. 2016;107:219-32.

47. Harder E, Damm W, Maple J, Wu C, Reboul M, Xiang JY, et al. OPLS3: A force field providing broad coverage of drug-like small molecules and proteins. J Chem Theory Comput. 2015;12(1):281-96.

48. Mangiatordi GF, Trisciuzzi D, Alberga D, Denora N, lacobazzi RM, Gadaleta D, et al. Novel chemotypes targeting tubulin at the colchicine binding site and unbiasing P-glycoprotein. Eur J Med Chem. 2017;139(20):792-803.

49. Miliutina M, Ejaz SA, Khan SU, laroshenko VO, Villinger A, lqbal J, et al. Synthesis, alkaline phosphatase inhibition studies and molecular docking of novel derivatives of 4-quinolones. Eur J Med Chem. 2017;126:408-20.

50. Alim I, Yuto K. Anti-methicillin-resistant Staphylococcus aureus (MRSA) activity of MC21-B, an antibacterial compound produced by the marine bacterium Pseudoalteromonas phenolica O-BC30T. Int J Antimicrob Agents. 2009;34(2):131-5.

51. Wang W, Liao Y, Tang C, Huang X, Luo Z, Chen J, et al. Cytotoxic and antibacterial compounds from the coral-derived fungus Aspergillus tritici SP2-8-1. Mar Drugs. 2017;15(11):348.

52. Xiao Y, Xue R, You T, Li X, Pei F, Wang X, et al. Gadolinium-1,4,7,10-tetraazacyclododecane-1,4,7,10-tetraacetic acid conjugate of arabinogalactan as a potential liver-targeting magnetic resonance imaging contrast agent. Carbohydr Res. 2014;395:9-14.

\section{Scheme}

Please see the Supplementary Files for the Scheme 1.

\section{Figures}


<smiles>O=C(O)c1cn(C2CC2)c2cc(N3CCNCC3)c(F)cc2c1=O</smiles>

$1 a$ ciprofloxacin<smiles>CNC1CCCN(c2c(F)cc3c(=O)c(C(=O)O)cn(C4CC4)c3c2OC)C1</smiles>

$1 e$ balofloxacin<smiles>CCn1cc(C(=O)O)c(=O)c2cc(F)c(N3CCNCC3)cc21</smiles>

1b<smiles>COc1c(N2CC3CCCNC3C2)c(F)cc2c(=O)c(C(=O)O)cn(C3CC3)c12</smiles>

$1 f$ moxifloxacin<smiles>COc1c(N2CCNC(C)C2)c(F)cc2c(=O)c(C(=O)O)cn(C3CC3)c12</smiles>

1c gatifloxacin<smiles>CC1COc2c(C3(N)CC3)c(F)cc3c(=O)c(C(=O)O)cn1c23</smiles>

$1 \mathrm{~g}$ pazufloxacin

Figure 1

The structure of fluoroquinolones modified in this paper.<smiles>[Z16]CN(CCN(CCN(CCN(CCN1CCN(c2cc3c(cc2F)c(=O)c(C(=O)O)cn3C2CC2)CC1)CC(=O)O)CC(=O)O)CC(=O)O)CC(=O)O</smiles><smiles>CCN(CCN(CCN(CC(=O)O)CC(=O)O)CN(CCN1CCN(c2cc(N=CC(=O)O)c(C(C)=O)cc2F)CC1)CC(=O)O)CC(=O)O</smiles><smiles>CN(CCN(CC(=O)O)CC(=O)N(C)C1CCCN(c2c(F)cc3c(=O)c(C(=O)O)cn4c3c2OCC4)C1)CC(=O)N(C)CCN(CC(=O)O)CC(=O)O</smiles>

$4 e$

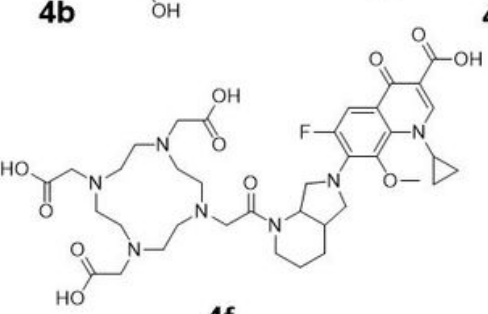

$4 f$<smiles>CCn1cc(C(=O)O)c(=O)c2cc(F)c(N3CCNCC3)nc21</smiles>

1d enoxacin

\section{Figure 2}

The structure of DOTA-fluoroquinolones conjugates. 


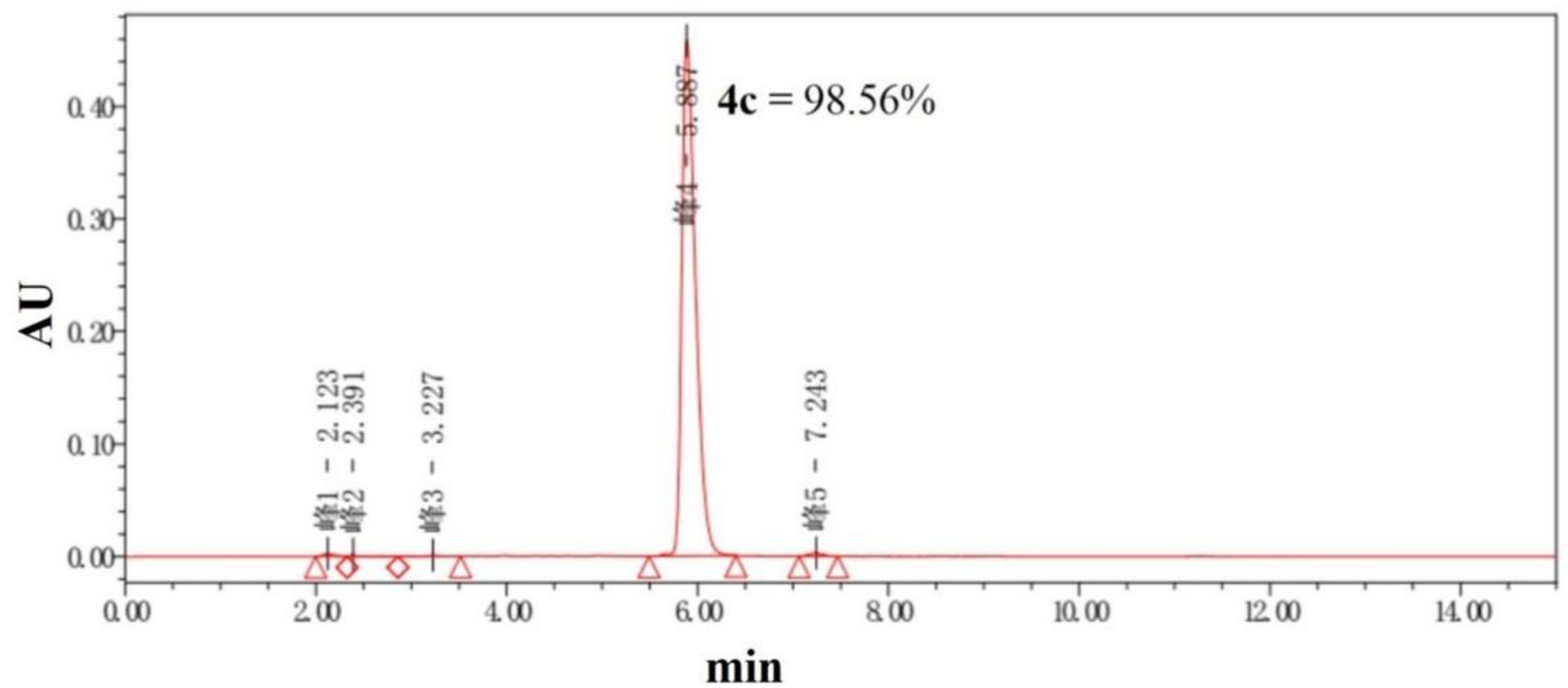

\section{Figure 3}

The purity of compound 4c analyzed by HPLC (Kromasil 100-5-C18 column $4.6 \times 250 \mathrm{~mm}$, eluted by A/B = 32:68 (A, acetonitrile: methanol = 70:30, v/v; B, water: methanol $=95: 5, \mathrm{v} / \mathrm{v}$ ) containing $0.1 \%$ TFA at a flow rate of $1 \mathrm{~mL} / \mathrm{min}$ ).
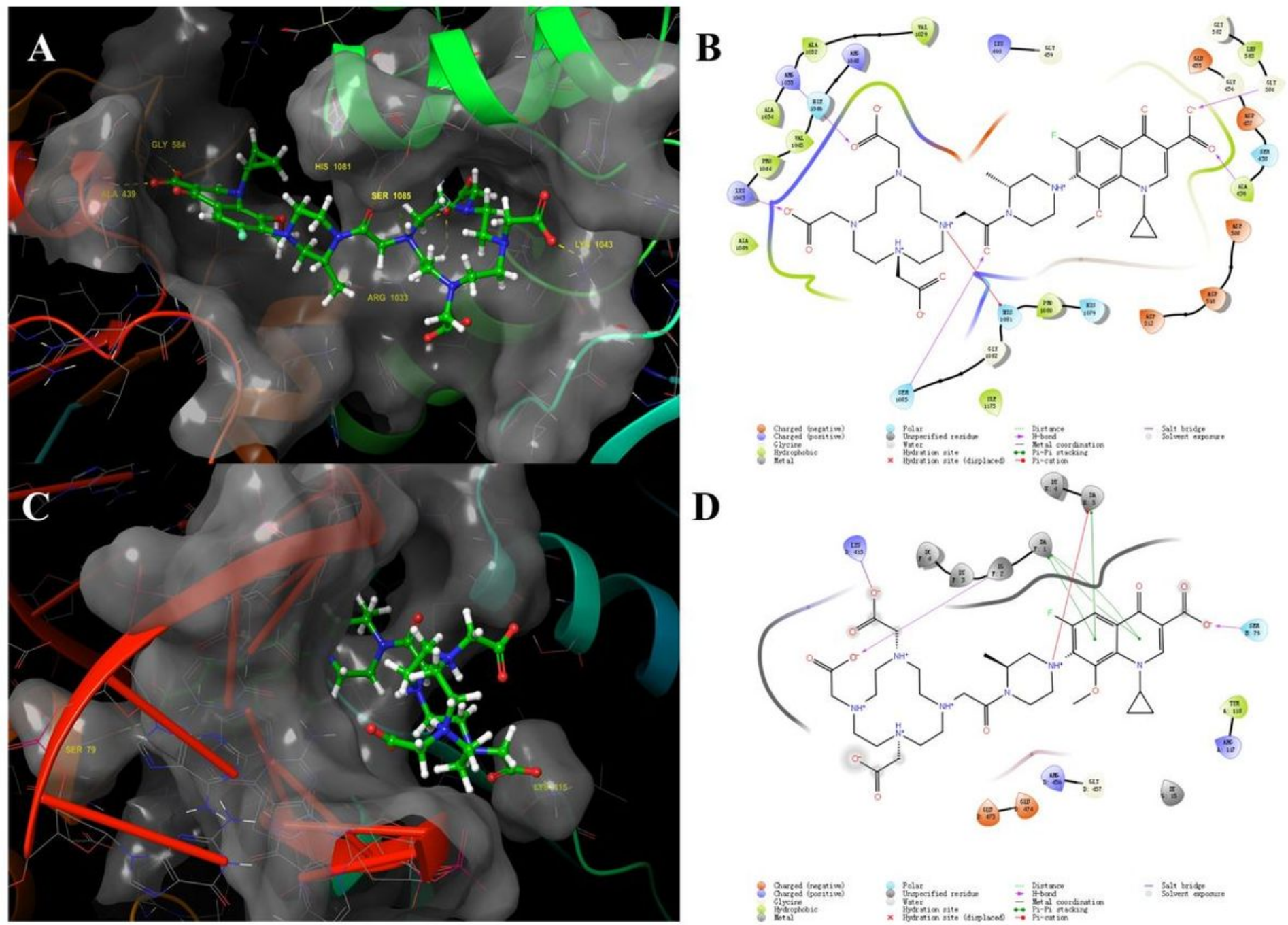
Figure 4

3D, 2D docking model of compound 4c with DNA gyrase $(A, B)$ and topoisomerase IV $(C, D)$.
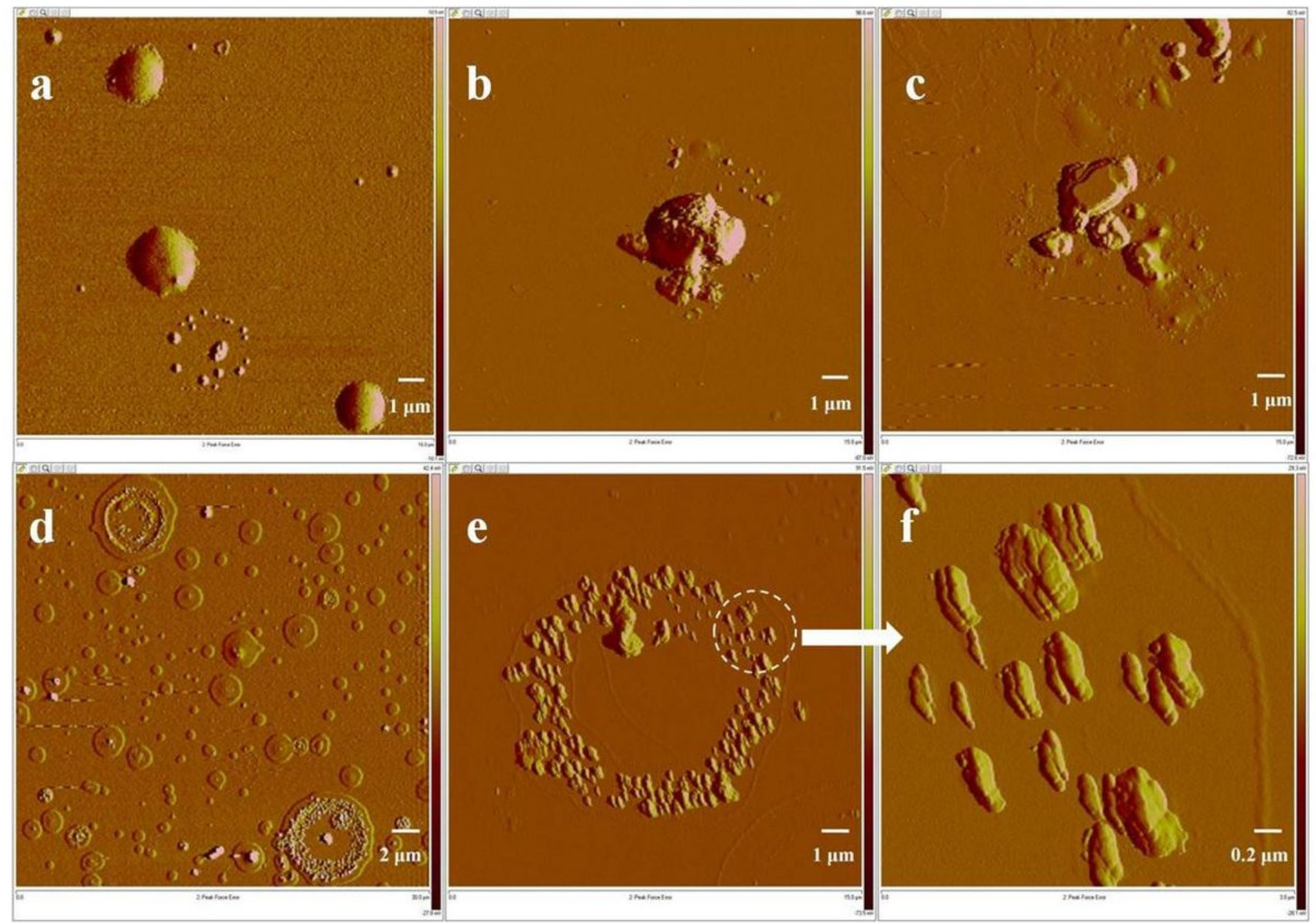

Figure 5

AFM image of MRSA strains (a) control, $16 \mu \mathrm{m}$; (b, c) treated by $10 \mu \mathrm{mol} / \mathrm{L}$ gatifloxacin (1c), $15 \mu \mathrm{m}$; (d) treated by $10 \mu \mathrm{mol} / \mathrm{L}$ gatifloxacinDOTA (4c) $30 \mu \mathrm{m}$; (e) $15 \mu \mathrm{m}$; (f) $5 \mu \mathrm{m}$. b, c were fields of view in different places of the same sample treated by 1c; $d$, e and f were the morphologic images for the MRSA strain treated by $4 c$, $f$ was the enlarged partial view of e.

A

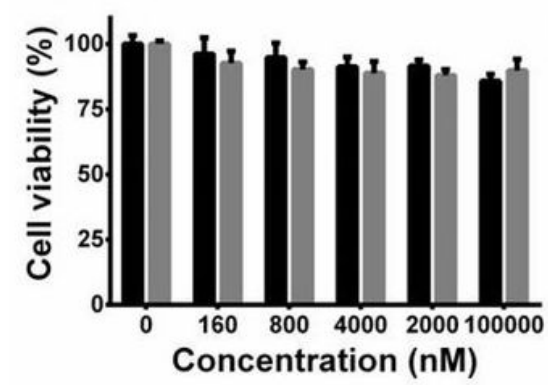

B

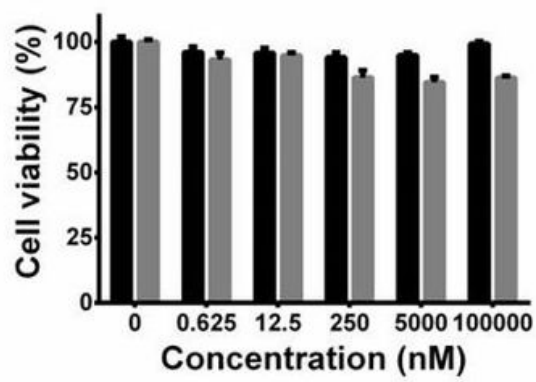

C

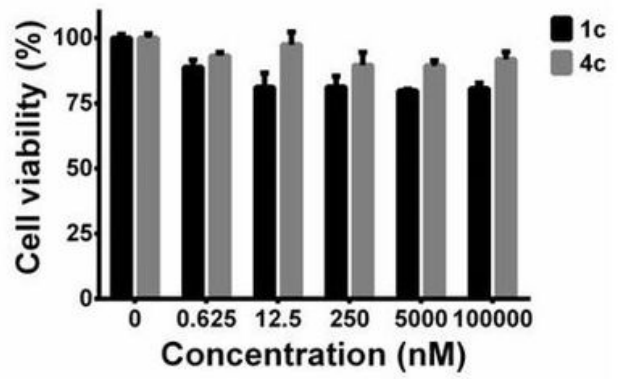

Figure 6

Cytotoxicity assay of L-02 cell (A), A549 cell (B), and MCF-7 cell (C) upon treated by compound 4c and 1c at different concentration. 
This is a list of supplementary files associated with this preprint. Click to download.

- GraphicalAbstract.docx

- supportinginformation.docx

- scheme1.jpg 